\title{
Heterogeneous ice nucleation properties of natural desert dust particles coated with a surrogate of secondary organic aerosol
}

\author{
Zamin A. Kanji ${ }^{1}$, Ryan C. Sullivan ${ }^{2,3}$, Monika Niemand ${ }^{4}$, Paul J. DeMott ${ }^{2}$, Anthony J. Prenni ${ }^{2, a}$, Cédric Chou ${ }^{1}$, \\ Harald Saathoff ${ }^{4}$, and Ottmar Möhler ${ }^{4}$ \\ ${ }^{1}$ Department of Environmental System Sciences, Institute for Atmospheric and Climate Science, \\ ETH Zürich, 8092, Zurich, Switzerland \\ ${ }^{2}$ Department of Atmospheric Science, Colorado State University, Fort Collins, CO 80523, USA \\ ${ }^{3}$ Center for Atmospheric Particle Studies, Carnegie Mellon University, Pittsburgh, PA 15213, USA \\ ${ }^{4}$ Institute of Meteorology and Climate Research, Karlsruhe Institute of Technology, 76344, \\ Eggenstein-Leopoldshafen, Germany \\ anow at: Air Resources Division, National Park Service, Lakewood, CO 80228, USA
}

Correspondence: Zamin A. Kanji (zamin.kanji@env.ethz.ch)

Received: 30 August 2018 - Discussion started: 10 September 2018

Revised: 30 March 2019 - Accepted: 4 April 2019 - Published: 16 April 2019

\begin{abstract}
Ice nucleation abilities of surface collected mineral dust particles from the Sahara (SD) and Asia (AD) are investigated for the temperature $(T)$ range $253-233 \mathrm{~K}$ and for supersaturated relative humidity $(\mathrm{RH})$ conditions in the immersion freezing regime. The dust particles were also coated with a proxy of secondary organic aerosol (SOA) from the dark ozonolysis of $\alpha$-pinene to better understand the influence of atmospheric coatings on the immersion freezing ability of mineral dust particles. The measurements are conducted on polydisperse particles in the size range $0.01-$ $3 \mu \mathrm{m}$ with three different ice nucleation chambers. Two of the chambers follow the continuous flow diffusion chamber (CFDC) principle (Portable Ice Nucleation Chamber, PINC) and the Colorado State University CFDC (CSU-CFDC), whereas the third was the Aerosol Interactions and Dynamics in the Atmosphere (AIDA) cloud expansion chamber. From observed activated fractions $(A F s)$ and ice nucleation active site (INAS) densities, it is concluded within experimental uncertainties that there is no significant difference between the ice nucleation ability of the particular SD and AD samples examined. A small bias towards higher INAS densities for uncoated versus SOA-coated dusts is found but this is well within the $1 \sigma(66 \%$ prediction bands) region of the average fit to the data, which captures $75 \%$ of the INAS densities observed in this study. Furthermore, no systematic differences are observed between SOA-coated and uncoated dusts
\end{abstract}

in both $\mathrm{SD}$ and $\mathrm{AD}$ cases, regardless of coating thickness $(3-60 \mathrm{~nm})$. The results suggest that any differences observed are within the uncertainty of the measurements or differences in cloud chamber parameters such as size fraction of particles sampled, and residence time, as well as assumptions in using INAS densities to compare polydisperse aerosol measurements which may show variable composition with particle size. Coatings with similar properties to that of the SOA in this work and with coating thickness up to $60 \mathrm{~nm}$ are not expected to impede or enhance the immersion mode ice nucleation ability of mineral dust particles.

\section{Introduction}

Ice nucleation in mixed-phase clouds (MPCs) is an important process that can significantly modify cloud microstructure, causing glaciation and initiating precipitation and thus impacting cloud albedo, lifetime and radiative properties. In the absence of ice crystals falling into the clouds from abovelying cloud layers, primary ice formation via heterogeneous freezing of aerosol particles at temperatures above $235 \mathrm{~K}$ is responsible for ice formation in MPCs. After primary ice formation, MPCs can fully glaciate due to secondary ice formation. Glaciation can also occur due to the co-existence of ice and liquid in the same environment causing ice crystals 
to grow at the expense of liquid droplets via the BergeronWegner-Findeisen process (Korolev, 2007). It is therefore important to quantify heterogeneous ice nucleation relevant to MPC temperatures to predict primary ice formation and subsequent secondary ice formation processes.

Contact and immersion freezing are the two known heterogeneous ice nucleation processes thought to be relevant to MPC formation conditions because they involve freezing of supercooled liquid water droplets. Contact freezing involves freezing initiated at the surface of supercooled droplets upon collision with aerosol particles. In immersion freezing, a supercooled droplet formed on an insoluble aerosol particle called an ice nucleating particle (INP) - will initiate freezing at the interface of the INP surface and the water droplet upon sufficient supercooling. A further distinction is made between immersion and condensation freezing. In immersion freezing, a droplet is formed at higher temperatures and undergoes supercooling before freezing, whereas in condensation freezing, the liquid water condensation occurs at supercooled temperatures and freezing is thought to be initiated at the same temperature during the liquid water condensation process or immediately thereafter.

A number of atmospheric particles have been shown to induce heterogeneous ice nucleation in the temperature regime above $235 \mathrm{~K}$ for a wide range in relative humidity (RH; Kanji et al., 2017). These can range from particles of biological origin associated with marine particles (Wilson et al., 2015; DeMott et al., 2016; Ladino et al., 2016; McCluskey et al., 2016), to those associated with terrestrial particles such as agricultural soil dust and leaf litter (Huffman et al., 2013; Prenni et al., 2013; Hill et al., 2014; Tobo et al., 2014; Steinke et al., 2016), desert dust (DeMott et al., 2010, 2015; Hoose and Möhler, 2012) and organic aerosol (DeMott et al., 2003a; Wang et al., 2012a; Knopf et al., 2014, 2018). The impact of these particles on ice formation processes in the troposphere is only quantifiable if their spatio-temporal distributions and burdens are well known. Mineral dust particles of desert origin have a significant tropospheric burden and role in heterogeneous ice nucleation both in laboratory experiments (Hoose and Möhler, 2012; Murray et al., 2012) and by inference from atmospheric observations (DeMott et al., 2003a, b; Chou et al., 2011; Cziczo et al., 2013; Boose et al., 2016a).

Mineral dust particles frequently accumulate secondary components such as acids during atmospheric transport (Bates et al., 2004; Arimoto et al., 2006; Sullivan et al., 2007a, b; Sullivan and Prather, 2007; Shi et al., 2008; Tobo et al., 2009). Observations of the ice nucleation activity of mineral dust coated with soluble material (mostly inorganic acids) are used as proxies for particles that undergo processes of atmospheric ageing during long-range transport. Varying degrees of suppression (none, partial or complete) in the ice nucleation activity of mineral dust particles due to inorganic or organic coatings or exposure to inorganic acid vapours have been observed and are dependent on the $\mathrm{RH}$ and $T$ regimes or chemical processing type of the dust particles (Archuleta et al., 2005; Möhler et al., 2008; Reitz et al., 2011; Tobo et al., 2012; Augustin-Bauditz et al., 2014; Wex et al., 2014; Freedman, 2015). Sullivan et al. (2010a, b) showed that at $243 \mathrm{~K}$ for $\mathrm{RH}$ with respect to water $\left(\mathrm{RH}_{\mathrm{W}}\right)$ $<100 \%$ in the deposition regime, $\mathrm{HNO}_{3}$ and $\mathrm{H}_{2} \mathrm{SO}_{4}$-coated Arizona test dust (ATD) particles exhibited lower activated fractions $(A F s)$ close to the detection limit - implying complete deactivation of ice nucleation activity - compared to uncoated ATD particles, a similar conclusion later reported by Kulkarni et al. $(2014,2015)$. However, for ice formation conditions at $\mathrm{RH}_{\mathrm{w}}>100 \%$ corresponding to the immersion freezing regime, the $\mathrm{HNO}_{3}$-coated particles yielded similar AFs to uncoated ATD (Sullivan et al., 2010a; Kulkarni et al., 2015) whereas the $\mathrm{H}_{2} \mathrm{SO}_{4}$-coated ATD exhibited lower AFs (partial deactivation) compared to the uncoated ATD in Sullivan et al. (2010b) but not in Kulkarni et al. (2014). A complete suppression of ice nucleation abilities in the immersion mode at 247 and $243 \mathrm{~K}$ and no suppression at $239 \mathrm{~K}$ for kaolinite particles coated with $\mathrm{H}_{2} \mathrm{SO}_{4}$ were also reported by Tobo et al. (2012). The response of ice nucleation to coatings below versus above water saturation was attributed to the dissolution of $\mathrm{HNO}_{3}$ and its reaction products from the dust particle surface following droplet activation at $\mathrm{RH}_{\mathrm{w}} \geq 100 \%$, thus restoring the ice-active sites for immersion freezing that had been impaired for deposition nucleation by the acid uptake (Sullivan et al., 2010a, b; Niedermeier et al., 2011a). In the case of the $\mathrm{H}_{2} \mathrm{SO}_{4}$ coating, it was concluded that the ice-active surface sites of the ATD were irreversibly chemically and probably morphologically modified, thus causing a reduction in the observed ice nucleation ability (Niedermeier et al., 2011a, b; Reitz et al., 2011) via all mechanisms. An alternative explanation is that $\mathrm{H}_{2} \mathrm{SO}_{4}$ can induce different chemical reactions with components of Arizona test dust than $\mathrm{HNO}_{3}$ can, and/or that the reaction products from $\mathrm{H}_{2} \mathrm{SO}_{4}$ chemistry are not dissolved off the mineral surface to restore the active sites after droplet activation (Sullivan et al., 2010b). Furthermore, for water supersaturated conditions and temperatures between 248 and $238 \mathrm{~K}$, Kulkarni et al. $(2014,2015)$ also report no influence of $\mathrm{H}_{2} \mathrm{SO}_{4}$ and $\mathrm{HNO}_{3}$ coatings regardless of coating thickness (between 1 and $40 \mathrm{~nm}$ ) on the ice nucleation activity of ATD, illite, feldspar and montmorillonite particles despite showing that the surface structural order of the coated particles had been modified. The authors concluded that products formed between the reactions of $\mathrm{H}_{2} \mathrm{SO}_{4}$ and the substrate aerosol (e.g. $\mathrm{Al}_{2}\left(\mathrm{SO}_{4}\right)_{3}$; Panda et al., 2010; Sihvonen et al., 2014) would dissolve in the immersion freezing regime, exposing the modified aerosol substrate active sites for ice nucleation. A suppression of ice nucleation activity for $\mathrm{RH}_{\mathrm{w}}<100 \%$ by $\mathrm{H}_{2} \mathrm{SO}_{4}$-treated kaolinite and montmorillonite particles between 235 and $245 \mathrm{~K}$ has also been reported by Sihvonen et al. (2014) and Chernoff and Bertram (2010), with the latter study showing a higher degree of suppression (higher RH required for ice nucleation). The degree of suppression in ice 
nucleation activity is likely related to the acid concentration and contact time with the particles prior to ice nucleation, with longer times and higher acid concentration leading to greater deactivation of the ice nucleating sample (Sihvonen et al., 2014). The suppression in ice nucleation activity due to $\mathrm{H}_{2} \mathrm{SO}_{4}$ coatings was linked to the formation of hydrated $\mathrm{Al}_{2}\left(\mathrm{SO}_{4}\right)_{3}\left(\mathrm{Al}_{2}\left(\mathrm{SO}_{4}\right)_{3} \cdot 17 \mathrm{H}_{2} \mathrm{O}\right)$ products, which surround the clay particles and deliquesce before freezing (at 240 and $245 \mathrm{~K}$ ) or nucleate ice via deposition at the coldest temperature investigated (235 K). Sihvonen et al. (2014) examined the same clay samples treated with $\mathrm{HNO}_{3}$ for their ice nucleation ability at the same $\mathrm{RH}_{\mathrm{w}}$ and temperature range. They observed a suppression in ice nucleation activity for kaolinite but not for montmorillonite and related this to the absence of the formation of a new product on the montmorillonite particles, despite its structure changing as observed through Xray diffraction measurements in agreement with Kulkarni et al. (2014, 2015). Lastly, the partial deactivation of kaolinite and ATD particles when exposed to high (parts-per-million level) concentrations of $\mathrm{O}_{3}$ have also been reported in both the deposition and immersion mode (Kanji et al., 2013). On the other hand, an enhancement in immersion freezing is reported, requiring warmer temperatures for freezing when trace amounts of $\left(\mathrm{NH}_{4}\right)_{2} \mathrm{SO}_{4}$ are added to aqueous droplets containing feldspar (microcline) particles compared to pure water droplets (Kumar et al., 2018; Whale et al., 2018). Similarly, enhanced immersion freezing was observed for kaolinite particles exposed to low $\mathrm{O}_{3}$ (parts-per-billion level) but no difference was observed for the same $\mathrm{O}_{3}$ exposure of ATD particles (Kanji et al., 2013). The discussion of results of ageing and coating experiments above strongly suggests that the type of substrate aerosol, coating or ageing component and regime of ice nucleation (water sub- or supersaturated) are all important considerations when assessing the impact of coatings or ageing on the ice nucleation activity of particles. It cannot be assumed that a coating or chemical processing will necessarily impair ice nucleation properties of mineral dust, in particular in the immersion freezing mode.

In the atmosphere, organic aerosol particles that are internally or externally mixed with other aerosol have also been identified as INPs, in particular under $T$ and RH conditions relevant for cirrus cloud formation (DeMott et al., 2003a; Richardson et al., 2007; Baustian et al., 2012; Knopf et al., 2018). Offline freezing analysis of atmospheric aerosol composed mostly of anthropogenic organics sampled onto substrates also showed ice nucleation activity in the immersion and deposition regimes. Probing of the specific INPs at the onset of ice initiation conditions revealed that compositions of particulates almost entirely organic in nature (Knopf et al., 2010) with no unique structural or compositional features (Wang et al., 2012b; Knopf et al., 2014). In laboratory studies organic glassy aerosol composed of raffinose, levoglucosan or citric acid were demonstrated to be INPs in the cirrus regime (Murray et al., 2010; Wilson et al., 2012), whereas oxalic acid, succinic acid and multicomponent mix- tures with $\left(\mathrm{NH}_{4}\right)_{2} \mathrm{SO}_{4}$ have been demonstrated to be effective INPs in the cirrus and MPC temperature regimes (Wagner et al., 2011, 2012, 2014, 2015). Studies of ice nucleation of secondary organic aerosol (SOA) surrogates from the reaction products of naphthalene and $\mathrm{OH}$ radicals (Wang et al., 2012a) found such particles to be effective at forming ice in both the immersion (for $T>230 \mathrm{~K}$, at $\mathrm{RH}<$ required for homogeneous freezing) and deposition mode (for $T<230 \mathrm{~K}$ ). However, another study that looked at ice nucleation of $\alpha$-pinene SOA and its reaction products with $\mathrm{OH}$ radicals (Ladino et al., 2014) found both sets of particles to be ineffective INPs requiring homogeneous freezing conditions to observe ice nucleation. Similar conclusions were reached for the ice nucleation ability of SOA produced from ozonolysis of 25 different alkene precursors (Prenni et al., 2009). Ladino et al. (2014) concluded that the detailed composition is not of paramount importance to the ice nucleating abilities of the SOA particles; however, particle conditioning such as precooling or pre-activation improved the observed ice nucleation ability. Given that the SOA particles studied by Wang et al. (2012a) acted as INPs, it may be that the parent particle composition or an experimental technique that allows appreciable cooling of aerosols prior to ice nucleation aids the ability of the aerosol to act as an INP. While overall the efficiency of organic aerosol to nucleate ice remains lower than that of mineral dust, the role of non-mineral aerosol in ice nucleation could be important in regions of the troposphere where mineral dust is scarce or absent.

The ubiquity of organic aerosol and the long residence times of dust in the troposphere can result in organic-mineral internally mixed particles (Russell et al., 2002; Maria et al., 2004; Sullivan et al., 2007a; Sullivan and Prather, 2007; Li et al., 2014). The ice nucleation properties of organic aerosol coatings on mineral dust as a proxy for such internal mixtures are therefore of interest to better understand the atmospheric relevance of ice nucleation of mineral aerosols. Tobo et al. (2012) reported that for kaolinite particles coated with levoglucosan (unreactive with kaolinite), deposition mode nucleation was suppressed (for $T>239 \mathrm{~K}$ ), but no suppression was observed for immersion mode ice nucleation. A deposition ice nucleation mode study by Möhler et al. (2008) showed significantly lower ice nucleation abilities for ATD and the clay mineral, illite coated with the oxidation products of $\alpha$-pinene and $\mathrm{O}_{3}$. A RH with respect to ice $\left(\mathrm{RH}_{\mathrm{i}}\right)$ of between 10 and $50 \%$ higher was required for coated particles to nucleate ice compared to uncoated particles in the temperature range $205-210 \mathrm{~K}$. This suggests that SOA coatings can alter the ice nucleating properties of freshly emitted mineral dust aerosol under water sub-saturated conditions and at temperatures relevant for the cirrus regime. Other than the study for levoglucosan-coated kaolinite (Tobo et al., 2012) there are no other laboratory studies reporting ice nucleation properties of organic-coated natural mineral dust in the MPC temperature regime $\left(T>233 \mathrm{~K}\right.$ and $\left.\mathrm{RH}_{\mathrm{w}} \geq 100 \%\right)$; however, a number of studies have been performed on particles 
composed of inorganic salts mixed with a variety of organic species (Parsons et al., 2004; Shilling et al., 2006; Wise et al., 2010; Knopf and Forrester, 2011) or on pure and multicomponent organic species (Fukuta, 1966; Prenni et al., 2009; Schill et al., 2014; Ignatius et al., 2016; Qiu et al., 2017). As mentioned above, the study by Möhler et al. (2008) explored only lower temperatures and water sub-saturated conditions. In this work, we present the ice nucleation properties of natural desert dust samples coated with the reaction products of $\alpha$-pinene and $\mathrm{O}_{3}$ as a proxy for secondary organic aerosol at $\mathrm{RH}_{\mathrm{w}}>100 \%$ and $253 \mathrm{~K}>T>233 \mathrm{~K}$ relevant to the MPC regime. To simulate atmospheric immersion freezing, we report results for conditions of supersaturation with respect to water, i.e. at thermodynamic conditions favourable for liquid water drops and ice crystals to form. It has been shown that operating continuous flow diffusion chambers (CFDCs), such as those used in this work, at sufficiently high $\mathrm{RH}_{\mathrm{w}}$, allows estimation of the maximum number of INPs that can activate at that temperature under the immersion freezing regime (DeMott et al., 2015). For example, activated fractions of dust INPs measured in a CFDC at $\mathrm{RH}_{\mathrm{w}}=105 \%$ were observed to be within a factor of 2 to 3 of the frozen fractions observed in immersion freezing measured in cloud chamber expansions (DeMott et al., 2015).

\section{Experimental methods}

The experiments described here were all conducted at the Institute of Meteorology and Climate Research at the Karlsruhe Institute of Technology in Karlsruhe, Germany, as part of the third Aerosol Cloud Interaction (ACI-03) campaign. Two CFDCs and the Aerosol Interactions and Dynamics in the Atmosphere (AIDA) expansion chamber were used for INP measurements. An aerosol preparation and characterization chamber (APC) with a volume of $3.7 \mathrm{~m}^{3}$ was used to suspend and prepare SOA-coated and uncoated desert dust particles. In this section, we provide a description of the methods and instruments used to measure the ice nucleation abilities of the coated and uncoated desert dust particles. The INP counters, PINC (Portable Ice Nucleation Chamber; see Sect. 3.2) and CSU-CFDC (Colorado State University - Continuous Flow Diffusion Chamber; see Sect. 3.3) both had aerosol sampling ports to access the APC chamber as shown in Fig. 1. The AIDA chamber was also filled with aerosol either directly from the aerosol generators or from the APC prior to cloud expansion experiments (see Fig. 1).

\subsection{Aerosol processing and sampling}

In this work, the ice nucleation properties of two different desert dusts samples were examined, Asian dust (AD) and Saharan dust (SD). Samples from these regions were chosen because emissions of dust from arid and semi-arid regions mainly come from the Saharan and Asian regions (Tang et

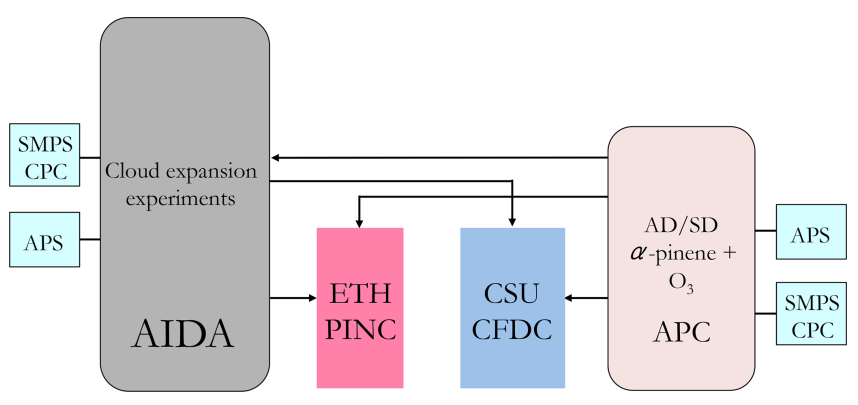

Figure 1. Experimental schematic of INP and aerosol sampling and sizing by cloud chambers and counting instruments at the AIDA facility at the Karlsruhe Institute of Technology during the ACI03 workshop in October 2009. APS: aerodynamic particle sizer, SMPS: scanning mobility particle sizer, CPC: condensation particle counter. See text for details on AIDA, ETH PINC and CSU-CFDC.

al., 2016 and references therein). The AD sample was collected off the surface in the eastern part of the Taklamakan Desert in China (east of the Dalimu basin between Ku'erle and Ruoqiang) while the SD soil sample was collected from a hole $1.5 \mathrm{~m}$ deep about $70 \mathrm{~km}$ north-east of Cairo city, Egypt (Ullrich et al., 2017). Both the SD and AD samples contain low amounts of total soluble ionic species $(0.63 \%$ and $0.45 \%$ by weight; Megahed, 2007) suggesting that there should be minimal influence of soluble matter and anthropogenic pollutants on the dust. The mineralogy of the dust particles has been investigated before for $\mathrm{AD}$ in the size fraction $<32 \mu \mathrm{m}$ (called Taklamakan in Boose et al., 2016b) and SD in the size fraction of $<20 \mu \mathrm{m}$ (labelled Cairo2 in Linke et al., 2006). Surface sampling was conducted for AD and SD so as to obtain enough sample mass to perform multiple ice nucleation experiments of coated (varying thickness) and uncoated dust samples using all three techniques presented here (see Sect. 2.3-2.4).

For aerosol generation, the dust samples were sieved to obtain a sub-fraction with diameters $<75 \mu \mathrm{m}$. Samples were introduced into the APC using a rotating brush generator (RGB -1000 , Palas, GmbH, Germany) which is operated with dry high-purity synthetic air. Aerosol particle counts and number size distributions in the APC chamber were monitored by a condensation particle counter (CPC 3010, TSI Inc.) and scanning mobility particle sizer (SMPS 3080 TSI Inc.) for particle sizes with mobility diameters in the range $14-820 \mathrm{~nm}$. In addition, an aerodynamic particle sizer (APS 3221, TSI Inc.) measured number size distributions of particles with aerodynamic diameters in the range $0.5-20 \mu \mathrm{m}$.

The SOA coating on the dust was applied at room temperature in the APC chamber by the in situ ozonolysis of $\alpha$ pinene. The addition of $\mathrm{O}_{3}$ to the dark chamber was always in excess of the amount of $\alpha$-pinene added to ensure complete reaction of the hydrocarbon to SOA products (Möhler et al., 2008). The SOA yield with respect to mass $\left(\mu \mathrm{g} \mathrm{m}^{-3}\right)$ of $\alpha$-pinene reacted is determined according to the param- 
eterization described in the work of Saathoff et al. (2009), which describes the formation of SOA from the ozonolysis of $\alpha$-pinene in the temperature range $233-313 \mathrm{~K}$. The SOA yield is mainly a function of the temperature and the amount of $\alpha$-pinene added to the APC chamber. The variation with temperature is not of much relevance to the production of SOA in the current work given that the SOA coatings were always generated at room temperature in the APC chamber. Considering the transport of the gas-phase SOA products to the dust particles, the condensation of the SOA vapours onto the desert dust particles occurs in the transition regime from the kinetic to the continuum regime described by the Knudsen number. In the kinetic regime, for particles smaller than the gas mean free path, the diameter growth rate of the SOA layer is influenced by the rate of random molecular collisions of vapour molecules with the particles and is independent of the particle size (Niemand, 2012). On the other hand, for particles larger than $0.5-1 \mu \mathrm{m}$ the growth rate becomes inversely proportional to the radius (continuum regime). It is therefore assumed that the coating thickness decreases with increasing particle size.

Representative dust particle number and surface size distributions are shown in Figs. 2 and 3 respectively for AD and SD. To convert mobility and aerodynamic diameters to volume-equivalent diameters, a shape factor of 1.4 for $\mathrm{AD}$ (1.2 for SD) and a particle density of $2.6 \mathrm{~g} \mathrm{~cm}^{-3}$ were used (Hiranuma et al., 2015). To determine the coating thickness, the total SOA produced is distributed over the surface area derived from the combined SMPS and APS measurements. In cases when a SOA only mode is formed as shown in Figs. 2 and 3, the mass of the SOA mode is subtracted (assuming spherical particles with density of $1.25 \mathrm{~g} \mathrm{~cm}^{-3}$ ) from the SOA yield (Saathoff et al., 2009) before distributing the SOA mass over the dust surface area to determine a mean coating thickness.

\subsection{The ETH Portable Ice Nucleation Chamber (PINC)}

Here we present a brief overview of PINC which is based on the original principle of the CSU-CFDC INP counter presented in Rogers (1988). A detailed account of the construction, operation validation and uncertainties can be found in Chou et al. (2011) and Kanji et al. (2013). PINC is a parallel-plate vertically oriented CFDC with anodized inner aluminium walls separated by a distance of $10 \mathrm{~mm}$. The inner chamber walls are coated with ice by flooding the chamber with water at $253 \mathrm{~K}$ for $20 \mathrm{~s}$, resulting in an ice coating thickness of $\sim 200 \mu \mathrm{m}$. In the chamber an aerosol flow is layered between two particle-free sheath flows so as to maintain a focused known location of the aerosol sample flow. The total flow rate of $10 \mathrm{~L} \mathrm{~min}^{-1}$ is composed of $1 \mathrm{~L} \mathrm{~min}^{-1}$ aerosol flow and two $4.5 \mathrm{~L} \mathrm{~min}^{-1}$ sheath flows to make a total sheath flow of $9 \mathrm{~L} \mathrm{~min}^{-1}$. The chamber is made up of a growth and evaporation section. Particles enter the growth region where a supersaturation with respect to ice and water are attained by
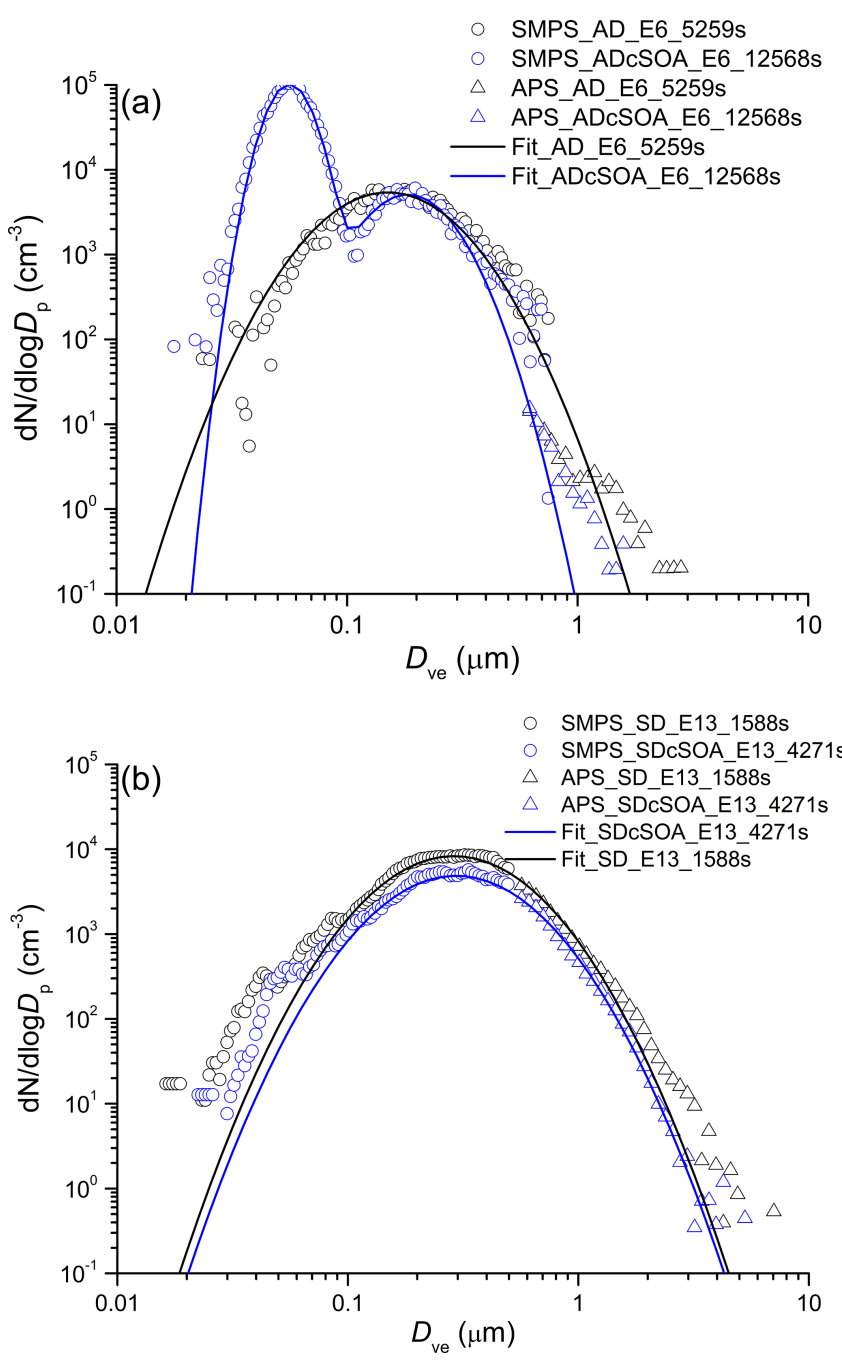

Figure 2. Exemplary number size (volume-equivalent diameter) distribution of $\mathrm{AD}$ (a) and SD (b) samples before and after coating with $\alpha$-pinene SOA. Nucleation of pure SOA particles results in the bi-modal distribution after SOA coating, giving rise to the mode at $40 \mathrm{~nm}$.

increasing the temperature difference between the two icecoated walls. An increase in RH is possible while keeping the sample temperature constant. Particle residence time in the growth region is $\sim 4$ to $5 \mathrm{~s}$ for the temperature regime studied here. After the growth region, particles pass into the evaporation section that is maintained at the same temperature as that of the warm wall, thus ensuring particles are exposed to ice saturation conditions corresponding to $\mathrm{RH}_{\mathrm{W}}<100 \%$, allowing for unfrozen liquid drops to shrink in size by evaporation. The residence time of the particles in this section is $\sim$ 1-2 s before being detected by the optical particle counter (OPC, CliMET, 3100) which is mounted downstream of the evaporation section. Particles larger than $3 \mu \mathrm{m}$ (optical diameter) are classified as ice crystals. To avoid misclassification of aerosol particles as ice crystals, particles enter the 

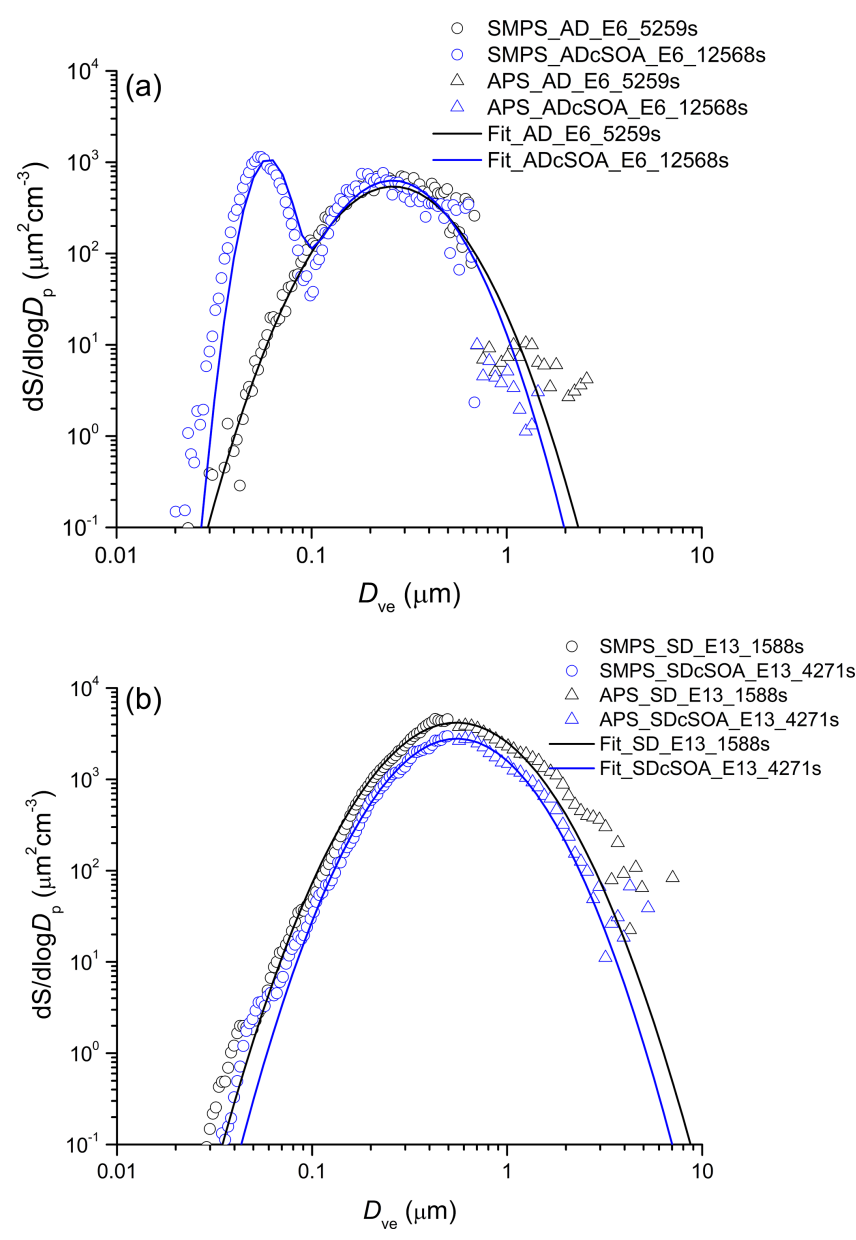

Figure 3. Same as Fig. 2 but for surface area distribution as a function of volume-equivalent diameter.

growth region through an impactor with a cut size of $0.7 \mu \mathrm{m}$ (volume-equivalent diameter determined using shape factor and density mentioned above). A typical experiment consists of sampling aerosol continuously from the APC chamber while changing the RH of the sample lamina from ice saturation to above water saturation to a maximum $\mathrm{RH}_{\mathrm{w}}$ above which droplets survive the evaporation region (water drop survival RH) upstream of being detected. Such a RH ramp takes $\sim 25 \mathrm{~min}$, resulting in an ice activation spectrum at a constant nominal sample temperature. Above the water drop survival $\mathrm{RH}_{\mathrm{w}}$, ice crystals can no longer be distinguished from droplets by size discrimination in the OPC. In PINC for temperatures $\leq 253 \mathrm{~K}$ the water drop survival region occurs at $\mathrm{RH}_{\mathrm{w}} \geq 107 \%$ and therefore all measurements are reported for $\mathrm{RH}_{\mathrm{w}}=105 \%$ to avoid signal contamination from unfrozen droplets when detecting ice in the OPC. The temperature measurement uncertainty in PINC is $\pm 0.1 \mathrm{~K}$ with a variability of temperature in the aerosol lamina of $\sim 0.6 \mathrm{~K}$. Uncertainty in reported RH mostly due to temperature uncertainties is on the order of $\pm 2 \% \mathrm{RH}_{\mathrm{w}}$ (absolute) for the temperature range reported in this work. Relative uncertain- ties in CPC and OPC measurements are on the order of $10 \%$, each leading to uncertainty in activated fraction of $\sim 15 \%$.

\subsection{The CSU-CFDC}

INP measurements were also conducted with the CSUCFDC model $1 \mathrm{H}$ whose basic description follows that provided in Rogers et al. (2001), with updates and modifications reported in Petters et al. (2009) and Eidhammer et al. (2010). Briefly, the CFDC consists of two (inner and outer) concentric copper cylindrical walls, oriented vertically, that form an annular gap of about $1.1 \mathrm{~cm}$ in which the laminar aerosol flow $\left(1.5 \mathrm{~L} \mathrm{~min}^{-1}\right)$ sampled from the APC chamber is sandwiched in between particle-free sheath flows $\left(8.5 \mathrm{~L} \mathrm{~min}^{-1}\right.$, divided on either side of the sample lamina). The inner and outer walls of the CSU-CFDC are coated with $\sim 100 \mu \mathrm{m}$ ice layers by pumping water through the chamber at $248 \mathrm{~K}$. The temperatures of the inner and outer walls along with the position of the sample layer determine the INP processing temperature and $\mathrm{RH}$ of the samples investigated. The residence time of the aerosols at a given experimental processing temperature is approximately $4-5 \mathrm{~s}$. The inner and outer walls of the lower third of the instrument are actively cooled and maintained at the colder (inner) wall temperature in order to drive conditions toward ice saturation so that particles that activated as droplets are evaporated in the exit region. This allows for clear optical detection of activated ice crystals. Particles that grow to sizes with optical diameters $>3 \mu \mathrm{m}$ are counted as ice crystals. In order to ensure that large particles are not sampled at the inlet of the chamber, an impactor with an aerodynamic particle cut-off size of $1.5 \mu \mathrm{m}$ (volume-equivalent diameter of $\sim 1 \mu \mathrm{m}$ assuming densities and shape factors listed above for mineral dust) is used to filter out larger particles that could be miscounted as ice. If processing conditions in the chamber growth region remain at $\mathrm{RH}_{\mathrm{w}}<108 \%$ at most temperatures, droplets will evaporate below sizes that would be detected as ice by the OPC (Climet, CI - 3100) (DeMott et al., 2015). We therefore only report data that are processed at $\mathrm{RH}_{\mathrm{w}}=105 \%$. Measurement uncertainties in the CSU-CFDC vary with processing conditions but are typically $\pm 0.5 \mathrm{~K}$ and $\mathrm{RH}_{\mathrm{w}} \pm 2.4 \%$ at $243 \mathrm{~K}$ (DeMott et al., 2015). Particle and ice crystal counting errors to compute $A F$ are on the order of $\pm 10 \%$ or less.

\subsection{AIDA expansion chamber}

The AIDA cloud expansion chamber operates on the principle of volume expansions that result in rapid cooling, thus increasing the RH inside a $84 \mathrm{~m}^{3}$ cylindrical chamber (Möhler et al., 2006). Details of the exact set-up used in the current work are reported in Niemand et al. (2012) and Wagner et al. (2012); however, we present a brief overview here. The AIDA chamber can be evacuated allowing expansion experiments with well-controlled and repeatable cooling rates of between 0.1 and $6 \mathrm{~K} \mathrm{~min}^{-1}$ corresponding to updraft veloci- 
ties of about 0.15 to $8 \mathrm{~m} \mathrm{~s}^{-1}$ covering a range from weakly to strongly convective wave clouds. The chamber is housed in a thermally insulated container that can be cooled down to $183 \mathrm{~K}$ with homogeneous temperature control $< \pm 0.3 \mathrm{~K}$. Typical background aerosol concentrations in the chamber are less than $0.1 \mathrm{~cm}^{-3}$. The chamber is evacuated to pressures as low as $0.01 \mathrm{hPa}$ before an expansion experiment and refilled with synthetic air to ensure clean conditions. Before a cloud expansion experiment, constant temperature and pressure conditions in the chamber maintain the $\mathrm{RH}_{\mathrm{i}}$ between $90 \%$ and $95 \%$ by means of a thin ice coating on the inner walls of the AIDA chamber. Under these conditions, the spatial and temporal temperature fluctuations are less than $\pm 0.2 \mathrm{~K}$, achieved by operating a mixing fan at the bottom of the chamber to ensure homogeneous conditions during experiments. Before an ice nucleation experiment is performed, a reference expansion where background particles are forced to activate as cloud droplets or ice crystals is performed which ensures precipitation of background particles from the chamber. A fresh sample of SOA-coated or uncoated dust is then transferred into the cloud chamber either directly from the aerosol generator or from the APC chamber. A tunable diode laser (TDL) is used to determine the water vapour pressure in situ with an accuracy of $5 \%$ (Niemand et al., 2012). In addition, total water concentration measurements were taken with a chilled-mirror hygrometer (373LX, MBW Calibration Ltd.). In cloud-free conditions, this compared to the TDL measurement to within 1\%-2\% (Fahey et al., 2014). Ice crystals and water droplets were detected with two welas OPCs (Palas, GmbH, Germany) (Benz et al., 2005). Ice crystals were distinguished from interstitial aerosol and water droplets by their size since ice crystals grow to much larger sizes at the expense of liquid droplets due to the lower equilibrium vapour pressure of ice compared to supercooled water. In addition, for the optical arrangement of the welas OPC, frozen droplets and ice crystals have much larger scattering intensity than liquid droplets of the same volume. The size threshold used to count ice crystals was variable and set for each experiment such that all counts from interstitial aerosol and water droplets were below this threshold. The aerosol particle number concentration in AIDA was measured with a CPC (3010, TSI Inc.) which was modified and calibrated to take continuous measurements at pressures from 100 to $1000 \mathrm{hPa}$. Number size distributions were taken with an APS (3221, TSI Inc.) and SMPS (3080, TSI Inc.) before every cloud expansion experiment. The counting uncertainties for aerosol number and ice crystal measurements for AIDA are $\pm 20 \%$ each, resulting in a total uncertainty of $\pm 28 \%$ in the $A F$.

\subsection{Active fraction $(A F)$ and ice nucleation active site (INAS density) determination}

For all ice chambers, $A F$ is reported by determining the ratio of ice counts from the OPC to the aerosol counts derived from the relevant CPC. Furthermore, assuming spherical particles, the number size distributions were converted into surface distributions that allowed for the derivation of ice nucleation active site (INAS) densities (Connolly et al., 2009; Hoose and Möhler, 2012; Murray et al., 2012; Beydoun et al., 2016). In determining the INAS density for experiments with PINC and CSU-CFDC we only considered surfaces areas of particles below 0.7 (1) and 1 (1.5) $\mu \mathrm{m}$ volume-equivalent (aerodynamic) diameter, respectively, owing to the use of impactors upstream of the chambers. The same consideration was not applied to determine $A F$ as the contribution of aerosol number above $1 \mu \mathrm{m}$ (see Fig. 2) is very small. However, the contribution to the surface area from the particles above $1 \mu \mathrm{m}$ is significant enough (see Fig. 3) to have to account for the impactors used upstream of PINC and CSUCFDC in determining INAS densities.

\section{Results and discussion}

$\mathrm{AD}$ and SD were tested for ice nucleation above water saturation (except at $233 \mathrm{~K}$ ), in the immersion mode in the temperature range 253 to $233 \mathrm{~K}$. For the CSU-CFDC and PINC experiments, ice nucleation abilities are reported for $\mathrm{RH}_{\mathrm{w}}=$ $105 \%$, which is in the thermodynamic regime favouring condensation of water prior to or during freezing. As such these data could have contributions from deposition nucleation but given that we expect droplet formation during air entry and cooling to the processing temperature in the INP chambers at these conditions (Welti et al., 2014), the contributions from deposition nucleation are expected to be negligible. We choose $\mathrm{RH}_{\mathrm{w}}=105 \%$ as this is the upper limit of reliable operation for PINC at the warmest temperature reported here $(253 \mathrm{~K})$ and is commonly used in reporting ambient CFDC data (Sullivan et al., 2010a, b; DeMott et al., 2017). To deduce the $A F$ (and INAS densities) at $\mathrm{RH}_{\mathrm{w}}=105 \%$ in PINC and CSU-CFDC, the $A F$ corresponding to $\mathrm{RH}_{\mathrm{w}}=104 \%$ $106 \%$ were averaged, and thus each data point presented represents an average of 10-20 data points (recorded every $5 \mathrm{~s}$ for PINC and $1 \mathrm{~s}$ for CSU-CFDC) depending on the rate of change of $\mathrm{RH}_{\mathrm{w}}\left(1 \%-2 \% \mathrm{~min}^{-1}\right)$. For the AIDA expansion, only those experiments where water drop formation was observed before ice formation are reported to ensure immersion freezing. Based on mineral dust experiments reported in DeMott et al. (2015) and correction factors presented in Garimella et al. (2017) we believe the $A F$ to be lower than those in AIDA by at least a factor of $\sim 3-4$ primarily due to aerosol particles escaping the lamina, resulting in exposure to lower $\mathrm{RH}_{\mathrm{w}}$ values than the computed $105 \%$. To aid the comparison presented below, the $A F$ values for PINC and CSU-CFDC have been increased by a factor of 3 based on the dust experiments' calibration factor reported in DeMott et al. (2015), which used some of the experiments presented in this work. 


\subsection{Activated fractions of uncoated and coated AD and SD}

Figures 4 and 5 show the $A F$ increasing as a function of decreasing temperature for $\mathrm{AD}$ and $\mathrm{SD}$ respectively, a trend expected and observed by all three methods as more iceactive sites become available at lower temperatures (see further discussion in Sect. 4.2). One of the first observations is that there is no significant nor systematic difference at the $p<0.05$ level $(\mathrm{AD} ; t$ value $=0.47, p$ value $=0.32$, SD; $t$ value $=-1.38, p$ value $=0.08$ ) between the $A F$ for coated and uncoated dusts in the immersion freezing regime for all ice chambers used in this work. Fit curves through the uncoated and coated data for both dusts with $95 \%$ confidence intervals (not shown) significantly overlap, further supporting the lack of difference. There is an indication that at higher temperatures, $T>245 \mathrm{~K}$, the CSU-CFDC observes lower $A F$ for the AD SOA particles (experiment 5 and 6 for AD SOA compared to 2 and 6 for AD). However, the fact that experiment 5 had a thicker SOA coating $(\sim 60 \mathrm{~nm})$ and a higher $A F$ compared to experiment 6 with a coating of $\sim 25 \mathrm{~nm}$ suggests that the differences could be due to size, with larger particles being more effective at activating to cloud droplets, solvating the coating and freezing by immersion. For $T \sim 245 \mathrm{~K}$ no difference between coated and uncoated dust was observed in AIDA and furthermore for $235<T<245 \mathrm{~K}$ both PINC and CSU-CFDC observed no differences between the AD and AD SOA. We thus conclude that in the immersion freezing regime, the SOA coating did not impact the ice nucleation ability of the AD samples tested here. This is in agreement with previous studies of $\mathrm{HNO}_{3}$ (Sullivan et al., 2010a; Kulkarni et al., 2015) and $\mathrm{H}_{2} \mathrm{SO}_{4}$ (Kulkarni et al., 2014) coatings on ATD, illite, kaolinite, montmorillonite and feldspars, all components of natural dust samples. For $233 \mathrm{~K}$ we report $A F$ for $\mathrm{RH}_{\mathrm{w}}$ between $95 \%$ and $98 \%$ to exclude bias from homogenous freezing that could occur at $\mathrm{RH}_{\mathrm{w}} \geq 100 \%$. We note that at $\sim 233 \mathrm{~K}$ data from PINC suggest a small coating effect, with $A F$ of AD SOA being slightly below that of AD. Depending on the mechanism of ice nucleation active here, this is not surprising given that similar coatings to that used here (Möhler et al., 2008) and inorganic acid coatings (Chernoff and Bertram, 2010; Sullivan et al., 2010a, b; Tobo et al., 2012; Kulkarni et al., 2014, 2015; Sihvonen et al., 2014) were reported to impede deposition mode nucleation (i.e. at $\mathrm{RH}_{\mathrm{w}}<100 \%$ ). However, given the insignificance in overall coating effects (see above) and size biases (see discussion below), one cannot exclude that at such high $\mathrm{RH}_{\mathrm{w}}$ water uptake into the SOA coating could have led to complete or partial solvation of the coating, leading to immersion freezing of the AD SOA sample at $233 \mathrm{~K}$.

Considering the results from the CSU-CFDC and AIDA chambers for all temperatures shown and for the $A F$ from PINC for $T<245 \mathrm{~K}$, the SOA coating on the SD does not appear to impact its ice nucleation ability in the immersion

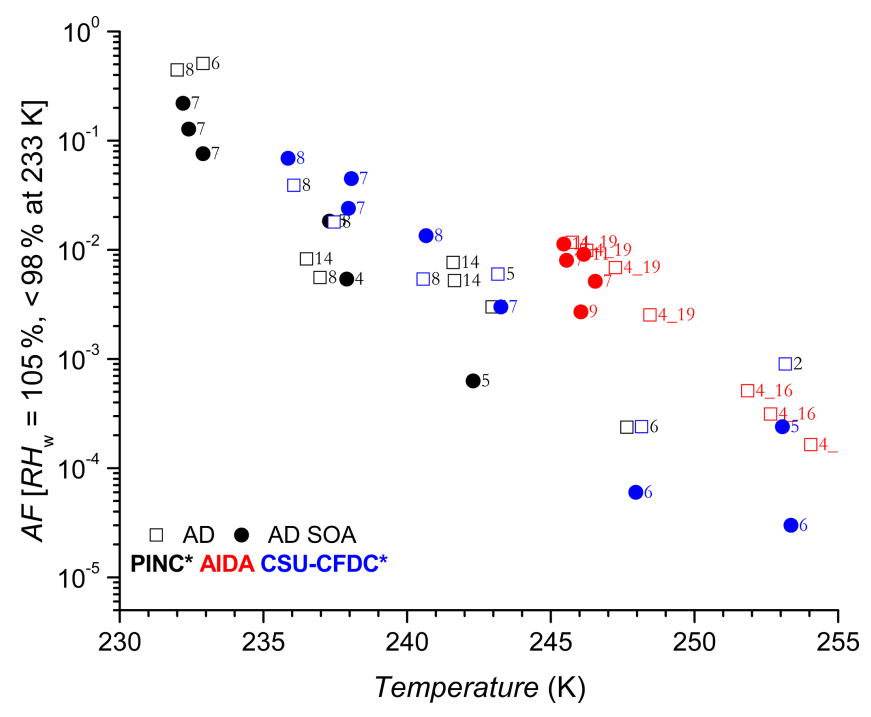

Figure 4. Activated fraction $(A F)$ as a function of temperature for Asian dust (AD, open squares) and AD coated with SOA (AD SOA, filled circles). Numbers next to data points refer to experiment number. Coating thicknesses are shown in Table 1 . The asterisk $\left(^{*}\right)$ denotes that the PINC and CSU-CFDC data have been increased by a factor of 3 (see text Sect. 4 for details). Error bars for $A F$ of $10 \%$ (CSU-CFDC), $14 \%$ (PINC) and $28 \%$ (AIDA) when plotted are hardly visible (not shown).

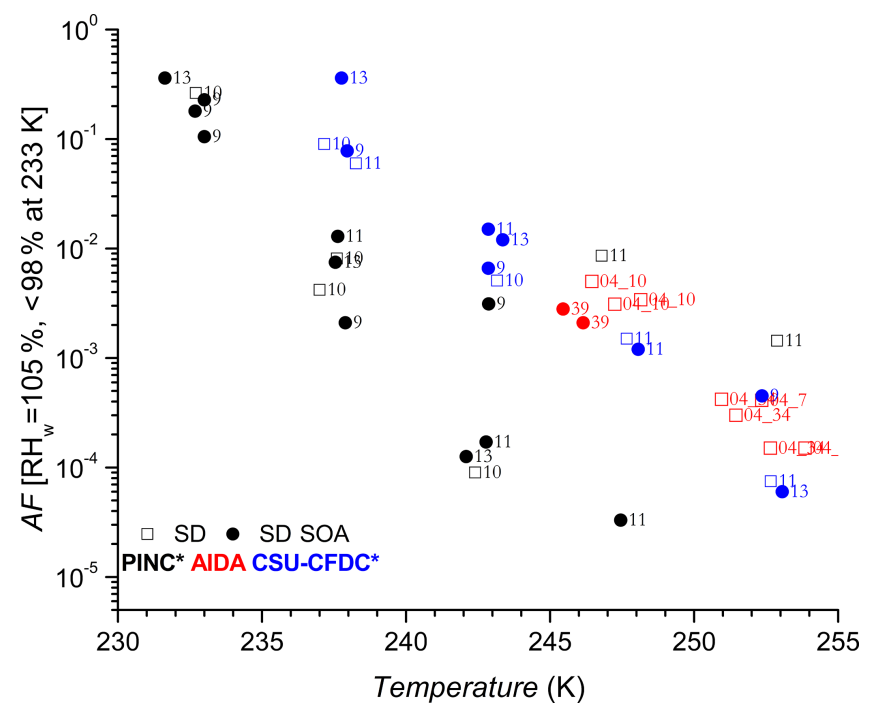

Figure 5. Same as Fig. 4, but for Saharan dust (SD) and SD coated with SOA (SD SOA) particles.

mode regardless of coating thickness (see also Fig. 6), similar to the conclusions from the $\mathrm{AD}$ results. At $\sim 248 \mathrm{~K}$ there appears to be a major suppression in $A F$ for experiment 11 in PINC, where the SD SOA has an $A F$ of 3 orders of magnitude lower than the $A F$ of SD. In general, the $A F$ data from PINC are at the lower end of the $A F$ range presented in Fig. 5 and could result from instrument differences discussed be- 
Table 1. Experiment number and corresponding SOA coating thickness calculated based on mass yield of SOA distributed equally over available dust surface area.

\begin{tabular}{ll}
\hline $\begin{array}{l}\text { Instrument and } \\
\text { experiment number }\end{array}$ & $\begin{array}{l}\text { Dust type }- \text { SOA coating } \\
\text { thickness }(\mathrm{nm})\end{array}$ \\
\hline CSU-CFDC/PINC & \\
\hline 04 & $\mathrm{AD}-3$ \\
05 & $\mathrm{AD}-60$ \\
06 & $\mathrm{AD}-26$ \\
07 & $\mathrm{AD}-9$ \\
08 & $\mathrm{AD}-15$ \\
09 & $\mathrm{SD}-12$ \\
11 & $\mathrm{SD}-7$ \\
13 & $\mathrm{SD}-8$ \\
\hline AIDA & \\
\hline 07 & $\mathrm{AD}-11$ \\
09 & $\mathrm{AD}-6$ \\
11 & $\mathrm{AD}-60$ \\
39 & $\mathrm{SD}-6$ \\
\hline
\end{tabular}

low. Other apparent differences in $A F$ between the SD and SD SOA particles are discussed only after consideration of particle size in the discussion below. The uncertainties in $A F$ (barely visible on the log plot and therefore not shown) are between $10 \%$ and $28 \%$ (see caption of Fig. 4 and methods) derived from aerosol particle and ice crystal counting statistics. This would imply that a difference in $A F$ by a factor of 2 or more is much greater than the maximum uncertainty in $A F$ $(28 \%)$ and therefore significant. Given that polydisperse particles were sampled in this work and that surface area plays an important role in ice nucleation, we normalize the $A F$ for surface area to determine INAS densities and reduce potential size biases (if any) that may cause the large spread in $A F$ for experiment 11 between the coated and uncoated dusts (see Sect. 3.2). The number of large particles sampled by each chamber will influence the reported AF since INP activity scales with dust particles size (Kanji and Abbatt, 2010; Lüönd et al., 2010) and thus large particles would contribute to the active INP population, resulting in higher $A F$. As such it is not surprising that AIDA shows the highest $A F$ compared to PINC and CSU-CFDC because of particle impactors applied upstream of PINC and CSU-CFDC which limit the largest particle sizes to 0.7 and $1.0 \mu \mathrm{m}$ volume-equivalent diameters, respectively. It is therefore also not surprising that the CSU-CFDC shows a somewhat higher $A F$ than PINC.

Time can also play an important role in promoting ice nucleation for both the deposition regime (Kanji and Abbatt, 2009) and immersion mode (Welti et al., 2012; Wex et al., 2014). The residence time in AIDA is the highest, on the order of a few minutes, whereas in PINC and CSU-CFDC it is much lower, on the order of 4-5 s. It could therefore be expected that the $A F$, which does not account for time, would

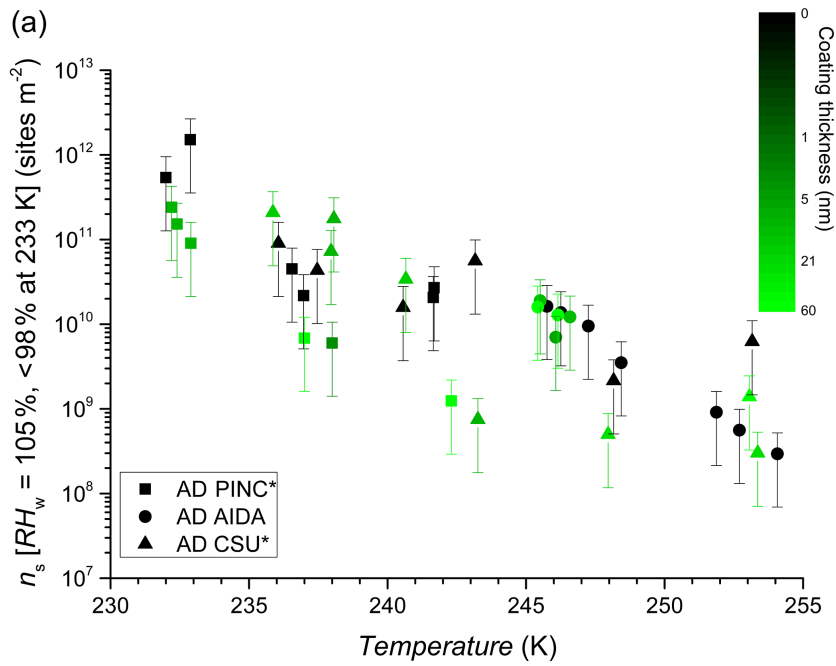

(b)

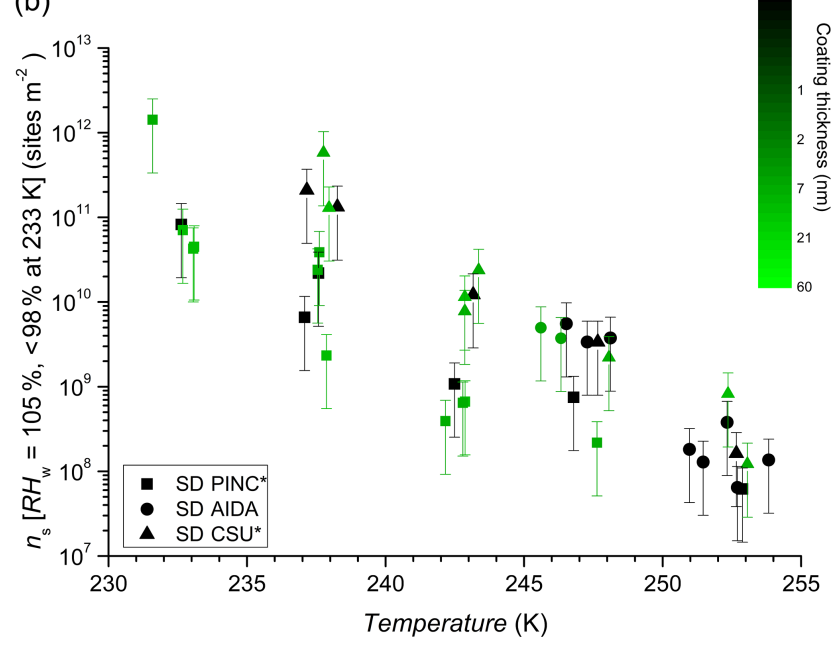

Figure 6. INAS densities as a function of temperature and SOA coating thickness for $\mathrm{AD}$ (a) and SD (b). Black symbols represent uncoated dust. Error bars are based on $75 \%$ sizing due to spherical assumption and surface area determination and $15 \%$ from particle counting resulting in a relative error of $77 \%$ in INAS density. The asterisk (*) denotes that PINC and CSU-CFDC data have been adjusted by a factor of 3 (see text Sect. 4 for details).

be lower in PINC and CFDC compared to AIDA. It is not expected that the OPC cut-off sizes for ice crystal threshold size (see Sect. 3.2 and 3.3) would influence the $A F$ for the $T$ and RH conditions reported here as growth rates to a few microns in diameter after nucleation of ice are expected to be almost instantaneous for $\mathrm{RH}_{\mathrm{w}}=105 \%$.

\subsection{INAS density of uncoated and coated Asian and Saharan dust}

The comparison using INAS densities for polydisperse aerosol samples is important to account for particle size because larger particles should be more ice-active (i.e. can nu- 
cleate ice at lower RH or supercooling (Archuleta et al., 2005; Kanji and Abbatt, 2010; Lüönd et al., 2010; BurkertKohn et al., 2017). The increases in INAS density as a function of decrease in temperature for $\mathrm{AD}$ and SD are shown in Figs. 6, 7 and 8. Compared to the $A F$ data where the maximum scatter of about a factor of 1000 is observed between 245 and $250 \mathrm{~K}$, by accounting for the surface area, the scatter reduces to within a factor of 100 (factor of 10 considering uncertainties) in the INAS density spectra. It is also evident from the INAS results in Figs. 7 and 8 that there is no systematic response of the ice nucleation activity of the dust particles to the presence of coatings, nor the thickness (see Fig. 6). An absence of the effect of organic (levoglucosan) and inorganic coatings on ice nucleation of mineral dust particles in the immersion mode has been reported previously (Sullivan et al., 2010a; Tobo et al., 2012; Kulkarni et al., 2014, 2015) and discussed above (see Sect. 1). There are a few indications of the SOA coating impeding ice nucleation by reducing the INAS of the coated particles, for experiments conducted with the CSU-CFDC and PINC. In particular, for $T>240 \mathrm{~K}$, AD SOA shows a lower INAS density for both instruments by up to a factor of 10 . At $T<240 \mathrm{~K}$, AD SOA INAS is lower than that of AD for PINC measurements, albeit by a smaller margin. For both PINC and CSU-CFDC the differences are all within the INAS uncertainties and thus are not significant (overlapping error bars). The thickness of the coating for the ranges tested here do not appear to play a role either, as shown in Fig. 6. At $\sim 238 \mathrm{~K}$ the PINC experiments 4 and 5 (Fig. 7) have about the same INAS density but the particle coating thickness is estimated to be 3 and $60 \mathrm{~nm}$ respectively. Similarly, at $\sim 254 \mathrm{~K}$ the CSU-CFDC experiments 5 and 6 have coating thicknesses of 60 and $26 \mathrm{~nm}$ respectively and INAS for AD SOA in experiment 5 is higher $\left(1.4 \times 10^{9} \mathrm{~m}^{-2}\right)$ than experiment $6\left(2.9 \times 10^{8} \mathrm{~m}^{-2}\right)$, suggesting that a thicker coating does not impede ice nucleation at these conditions.

The INAS density for SD and SD SOA in Fig. 8 show increased scatter compared to the AD results, especially at temperatures of 238 and $243 \mathrm{~K}$. At warmer temperatures, the scatter in INAS density is largely reduced, indicated by the overlapping data and error bars. At the colder temperatures, PINC data are biased towards lower INAS densities than CSU-CFDC. When considering the data obtained by each instrument separately, there is no difference between the ice nucleation ability of SD and SD SOA, a consistent conclusion for all three instruments. Similar to AD, the coating thickness did not influence the ice nucleation ability of the SD particles, as shown in Fig. 6. Studies that reported partial (Sullivan et al., 2010b; Tobo et al., 2012) and complete (Augustin-Bauditz et al., 2014) deactivation in the immersion mode freezing of dust particles due to coatings of $\mathrm{H}_{2} \mathrm{SO}_{4}$ looked at coating thicknesses between 1 and $15 \mathrm{~nm}$, overlapping with the range of 3-60 $\mathrm{nm}$ tested in this work. In particular, Augustin-Bauditz et al. (2014) report an influence on immersion mode ice nucleation activity of feldspar with

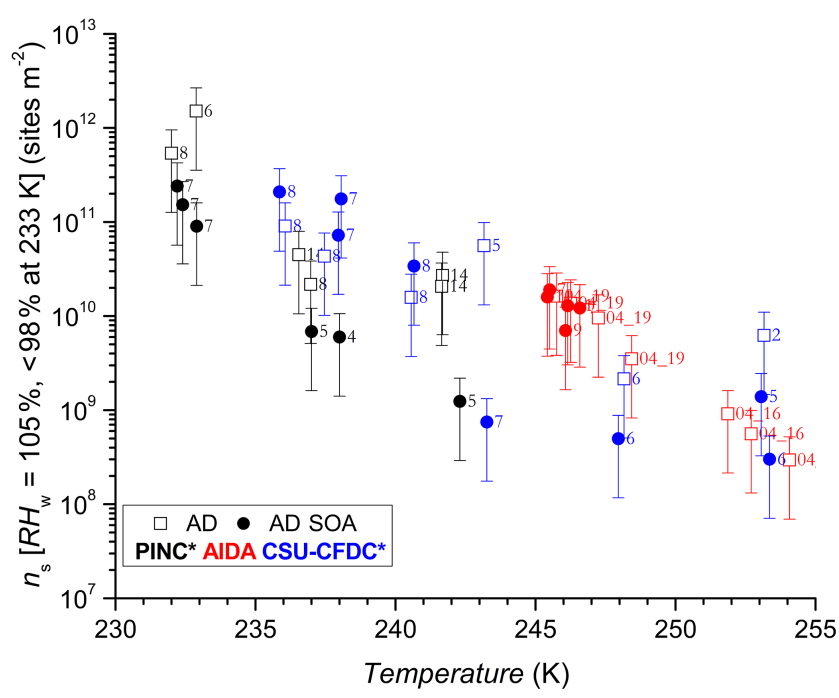

Figure 7. INAS densities as a function of temperature for AD and AD SOA. Error bars are based on $75 \%$ uncertainty in particle sizing due to spherical assumption and surface area determination and $15 \%$ uncertainty from particle counting resulting in a relative error of $76 \%$ in INAS density. Numbers next to data points refer to experiment number records for coating thicknesses shown in Table 1. The asterisk $\left(^{*}\right)$ denotes that the PINC and CSU-CFDC data have been adjusted by a factor of 3 (see text Sect. 4 for details).

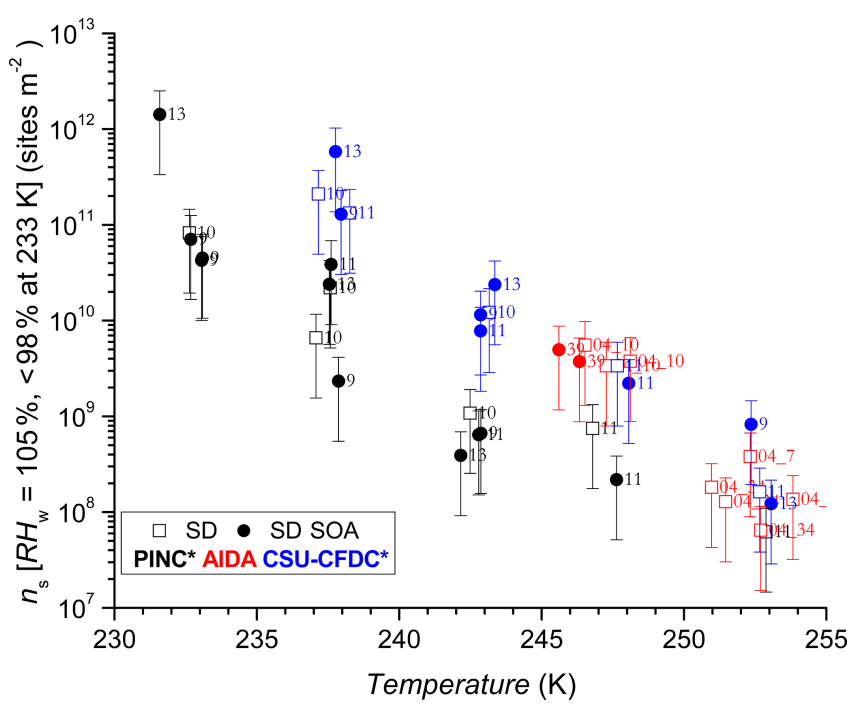

Figure 8. Same as Fig. 7 but for Saharan dust (SD) and SD coated with SOA (SD SOA) particles.

the thicker $\mathrm{H}_{2} \mathrm{SO}_{4}$ coatings ( $15 \mathrm{~nm}$ ), resulting in lower frozen fractions than those with thinner $\mathrm{H}_{2} \mathrm{SO}_{4}$ coatings $(3 \mathrm{~nm})$. This is similar to conclusions drawn earlier by Sullivan et al. (2010b), who also found significant lowering of the $A F$ in the immersion mode when $\mathrm{H}_{2} \mathrm{SO}_{4}$ coating thickness increased progressively from 1 to 2.4 to $4.1 \mathrm{~nm}$ with the $A F$ for the latter coating thickness at the edge of the limit of quan- 
tification. On the other hand, studies that did not observe an effect of coating also do not report an effect of coating thickness. For example Kulkarni et al. (2014) report no effect of 1 and $40 \mathrm{~nm}$ thick $\mathrm{H}_{2} \mathrm{SO}_{4}$ coating on a variety of mineral dust particles in the immersion mode. We note that the coatings discussed in the studies above are produced by transiting particles through heated vapour regions of the coating substance. As such thicker coatings are associated with a higher processing temperature, which could have an effect on the ice nucleation activity by enhancing reactions between the coating and the substrate particles. Sullivan et al. (2010b) showed that thermo-denuding $\mathrm{H}_{2} \mathrm{SO}_{4}$-coated ATD particles at $523 \mathrm{~K}$ further reduces their ice nucleation activity compared to particles with the same coating thickness without thermo-denuding.

In our work, during sample generation, we cannot exclude the possibility of uneven coatings on the natural dust particles due to their highly irregular shape, size and porous features thus having potential for exposed mineral dust surface sites even in the coated particles. Assuming thicker coatings block water access to the dust surface, or require larger diffusion timescales of water through the coating, we would expect a suppression in INAS density for thicker coatings compared to dust with thinner coatings, in particular over the short timescales in our flow chambers. However, this is not observed and could be due to the high supersaturated $\mathrm{RH}_{\mathrm{w}}$ used to evaluate the maximum ice nucleation in the immersion mode. The SOA coatings were formed and condensed onto the $\mathrm{AD}$ and $\mathrm{SD}$ at room temperature and at very dry conditions of $\mathrm{RH}_{\mathrm{w}}<10 \%$, implying that the coatings could have formed viscous (Maclean et al., 2017) glassy phases which have been reported to readily form at $\sim 298 \mathrm{~K}$ and $\mathrm{RH}_{\mathrm{W}} \ll 50 \%$ (Wagner et al., 2012). In particular, Kidd et al. (2014) have shown specifically for $\mathrm{O}_{3} / \alpha$-pinene SOA that if formed at low $\mathrm{RH}$ as was done in our work, the SOA remains in a highly viscous and solid state even upon significant increase of $\mathrm{RH}_{\mathrm{w}}$ up to $85 \%-90 \%$. The transition of $\mathrm{RH}_{\mathrm{w}}$ to liquid SOA being higher than reported elsewhere (Liu et al., 2016; Ye et al., 2016; Gorkowski et al., 2017; McFiggans, 2018) is likely due to the low temperature during exposure to high RH in our ice nucleation experiments. Indeed the transition from solid to a semi-solid or glassy state, for a variety of organic compounds forming internally mixed SOA as would be expected with $\mathrm{O}_{3} / \alpha$-pinene SOA (Hallquist et al., 2009), is reported to occur at $\mathrm{RH}_{\mathrm{w}}=75 \%-$ $85 \%$ over the temperature range $250-230 \mathrm{~K}$ (Wang et al., 2012a). For the same temperature range, other estimates of SOA proxies find the transitions to liquid from a glassy state occur at $\mathrm{RH}_{\mathrm{w}}<85 \%$ (Ladino et al., 2014) and 50\%-65\% (Koop et al., 2011). Given that we report data for conditions of $\mathrm{RH}_{\mathrm{w}} \geq 100 \%$, water condensing on the particles likely penetrates or dissolves the glassy-state SOA by diffusing into the SOA coating, thus forming dilute droplets which freeze heterogeneously via the immersion mode. The hygroscopicity parameter, $\kappa$, of $\alpha$-pinene SOA has been reported to be $0.10-0.14$ (Jurányi et al., 2009) compared to 0.017 (Augustin-Bauditz et al., 2016) for uncoated dust particles. Therefore, oxidized organic coatings such as the SOA used here can even enhance water uptake of the coated dust particles, thus favouring immersion mode freezing as opposed to suppressing ice nucleation in the deposition mode (Möhler et al., 2008). The presumed highly viscous nature of the SOA formed at the conditions used here could leave parts of the mineral surface exposed and thus able to act as an INP. The possibility of incomplete coatings in our sample generation could explain the similarities in $A F$ or INAS density of the coated and uncoated dust. This would explain why a difference in INAS density is not consistently observed for coated dusts compared to uncoated dusts. Lastly, it has been observed that glassy naphthalene SOA served as immersion INPs after water uptake for $243 \mathrm{~K}>T>233 \mathrm{~K}$ and under water saturation conditions (Wang et al., 2012b). For the same particles at $T>243 \mathrm{~K}$, however, water uptake occurred between $\mathrm{RH}_{\mathrm{w}}$ of $80 \%$ and $90 \%$ depending on the $\mathrm{O} / \mathrm{C}$ ratio but did not freeze upon reaching water saturation. The authors concluded from water diffusivity calculations that at the warmer temperatures water penetrates and dissolves the SOA that would otherwise act as an immersion INP at the colder temperatures (Wang et al., 2012b). In this work, solvation of the SOA coating can still render the particle ice nucleation active due to the mineral dust core, as indicated by the observed $A F$ and INAS density for temperatures as warm as $253 \mathrm{~K}$.

Experiments with similar SOA coatings as used in this work were reported for illite clay mineral particles and ATD from the AIDA chamber (Möhler et al., 2008) for a lower temperature range of $210-215 \mathrm{~K}$. It was found that for the same $\mathrm{RH}_{\mathrm{i}}=120 \%$, the SOA-coated ATD yielded an $A F$ of a factor of 15 lower than uncoated ATD. For illite particles, almost complete activation $(A F \sim 1)$ was observed at $\mathrm{RH}_{\mathrm{i}}=120 \%$, but the SOA-coated illite did not show any ice formation until $\mathrm{RH}_{\mathrm{i}}=160 \%$ was reached (homogeneous freezing conditions at the temperature reported), suggesting that under these conditions $\left(\mathrm{RH}_{\mathrm{W}} \ll 100 \%\right.$, deposition mode regime) the organic coating significantly suppresses ice nucleation for dust particles (Möhler et al., 2008). Considering the temperature and $\mathrm{RH}$ range (deposition mode regime) of the study, adsorbed water may not be able to diffuse through and solvate the SOA coatings on the short observation timescales of AIDA ( $\sim 120 \mathrm{~s}$ during an expansion), suggesting that the ice nucleating active sites on the surface of the dust are blocked from potentially stabilizing ice germ formation. Furthermore, the difference in magnitude of ice nucleation suppression could be attributed to the fact that ATD likely had much thinner coating (mass fraction of SOA to ATD $17 \%$ ) compared to a thicker coating on illite with a mass fraction of SOA of $41 \%$ (Möhler et al., 2008). The absence of a SOA coating effect on the immersion freezing of dust particles observed here could imply that, first, the organic coating produced here did not modify the active sites 
on the mineral dust surface thus re-exposing them upon dissolution into the droplet and, second, if the surface was modified, equally potent active sites were exposed on the mineral dust surface, retaining its average ice nucleation activity. This is in contrast to the effect of coatings with $\mathrm{H}_{2} \mathrm{SO}_{4}$ that were shown to irreversibly modify mineral dust INPs in the immersion mode (Sullivan et al., 2010b; Tobo et al., 2012; Augustin-Bauditz et al., 2014).

\subsection{Comparison of coated to uncoated dusts for the three INP chambers}

During the measurements conducted in this work, one of the goals was to achieve an inter-comparison of sampling INPs between the techniques used. To do this, in Figs. 9 and 10 we have plotted data for the INAS density of coated versus uncoated dusts without distinguishing between $\mathrm{AD}$ and $\mathrm{SD}$, for each of the three instruments used. Here, the influence of the method and instrument type on any observed differences in ice nucleation activity between the coated and uncoated particles should be normalized. To match the coated to the uncoated INAS densities, the data are binned into $1 \mathrm{~K}$ bins $( \pm 0.5 \mathrm{~K})$ for each instrument used (Fig. 9). To show the temperature regime where the difference in INAS density between coated and uncoated dusts is the highest, the data were binned only by temperature but without distinguishing for the instruments (Fig. 10). We note that based on the earlier discussed comparisons (see end of Introduction and end of Sect. 3), the CSU-CFDC and PINC data have been increased by a factor of 3 , to account for the low bias of INP concentrations and $A F$ that is typical in CFDC INP counters, as discussed by DeMott et al. (2015).

Figure 9 reveals that for $I N A S_{(\mathrm{SOA}, \text { coated) }}>10^{10} \mathrm{~m}^{-2}$ ( $y$ axis), all data points (except one outlier) lay on or overlap with the $1: 1$ line considering uncertainties (shown as the error bars), suggesting no differences in ice nucleation activity between coated and uncoated dusts irrespective of instrument used or dust type sampled. Below this value, fewer data points lay on the 1:1 line with a visible bias to lower INAS density regardless of the instrument used in this study, suggesting a slight bias towards coated dusts having an impeded ice nucleation ability in the range $I N A S_{\text {(SOA, coated) }}<$ $10^{10} \mathrm{~m}^{-2}$. Furthermore, the ice nucleation suppression appears to be higher for CSU-CFDC and PINC than for AIDA, with the latter having all data points within a factor of 10 of the $1: 1$ line, but a few data points being outside this factor of 10 region for PINC ( 1 for CSU-CFDC). The difference between the continuous flow chambers and AIDA may be attributed to the shorter residence times of 4-5 s compared to those of minutes in AIDA, which would allow diffusion of water and possibly dissolution of the SOA coating for immersion freezing to occur in this temperature range. The fraction of large particles $(>1 \mu \mathrm{m})$ sampled by AIDA was also higher and could contribute to the observed higher INAS of the coated dusts. Compared to AIDA and CSU-CFDC, PINC

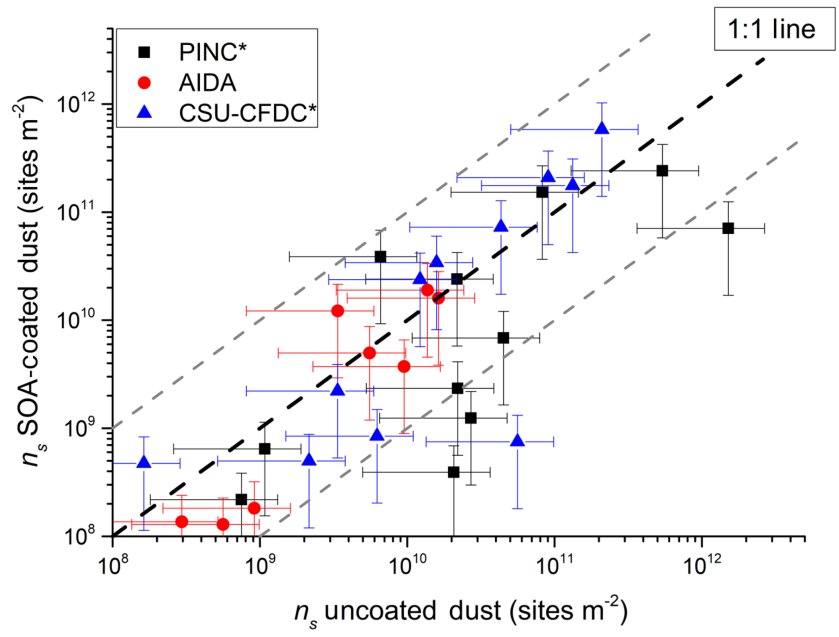

Figure 9. Comparison of ice nucleation activity of uncoated dusts with coated dusts distinguished by the three cloud chambers used in this study. Data are binned by temperature into $1 \mathrm{~K}$ bins for each cloud chamber. The grey dashed lines represent a factor of 5 from the $1: 1$ line. Error bars in $n_{\mathrm{S}}$ represent a relative uncertainty in sizing and counting particles of $76 \%$ (upper estimate).

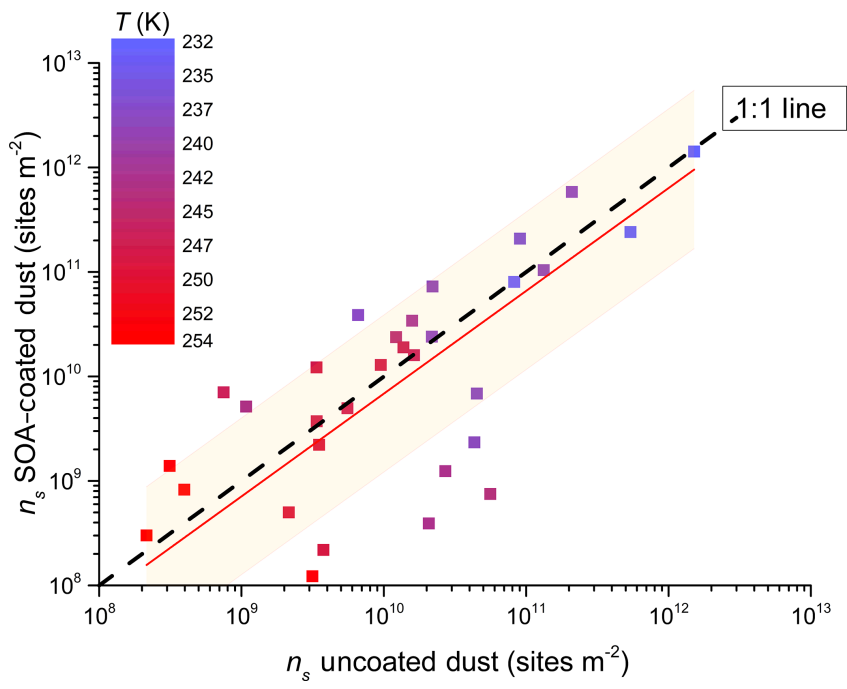

Figure 10. Same as Fig. 8 but binned by temperature into $1 \mathrm{~K}$ bins not accounting for cloud chamber type as a function of temperature. Error bars omitted for clarity of temperature colour bar. Dashed line is $1: 1$ fit and red line is linear fit to data $n_{\mathrm{S}}$ (coated) $=n_{\mathrm{S}}$ (uncoated) with forced intercept $(0,0)$ with $r^{2}=0.99$. Shaded region represents $66 \%$ prediction bands of fit.

INAS density shows positive bias towards uncoated dusts. In addition, two data points, one from each PINC and CSUCFDC, lie outside the factor of 10 line (Fig. 9) even considering uncertainties, which may suggest that the coatings on the dust may occasionally impact the immersion freezing activity (for example for a complete thick SOA coating). However, given the large spread of data in the range 
$10^{8}<I N A S_{\text {(SOA, coated) }}<10^{10} \mathrm{~m}^{-2}$, it is not possible to disentangle beyond the discussion in Sect. 4.1 and 4.2 what the reasons could be for the sometimes observed suppression in INAS density of the coated dusts. From a previous comprehensive intercomparison study on the immersion freezing of illite particles (Hiranuma et al., 2015), agreement between 17 ice nucleation instruments was found within a factor of 10 in INAS density. The fact that $95 \%$ of the data points in Fig. 9 lay within or overlap (with uncertainties) the factor of 10 region of the $1: 1$ line suggests that there is no difference in ice nucleation ability of the coated and uncoated dusts and any small differences observed could be instrument or experiment specific.

Furthermore, the coated versus uncoated dust INAS densities plotted in Fig. 10 do not distinguish for the instrument used but show the temperature dependency instead. Similar to the previous discussion, a higher spread in the data from the $1: 1$ line is observed for warmer temperatures (lower INAS values). A factor contributing here again is that larger particles with varying composition can bias towards higher INAS values. We note that there is also some spread at $I N A S<10^{11} \mathrm{~m}^{-2}$, suggesting that uncoated dust particles have higher INAS values. In addition, $80 \%$ of the data fall within the factor of 10 of the $1: 1$ line (Fig. 10). Fitting the data with a linear fit (with a forced $(0,0)$ intercept) yields a slope of $<1$, suggesting a slight bias towards the ice nucleation activity of uncoated dusts being higher than coated dusts. However, the $66 \%$ (95\%) confidence interval prediction bands of the fit show that $75 \%(97 \%)$ of the data are predicted by this fit, suggesting that overall there is no influence on the immersion mode ice nucleation activity caused by the SOA coatings used in this study for either type of desert dust.

\subsection{Comparison of ice nucleation properties of Asian and Saharan dusts}

In Fig. 11, we show the INAS for $\mathrm{AD}$ and $\mathrm{SD}$ as a function of temperature. We note there is no significant difference between the two dusts at the $p<0.05$ level $(t$ value $=1.24$, $p$ value $=0.11)$ in their ice nucleation activity at these conditions. This is especially visible in Fig. 11 considering experimental uncertainties as shown by the error bars that mostly arise from particle counting and sizing. Fitted curves to the $\mathrm{AD}$ and SD data separately resulted in completely overlapping confidence interval bands at the $95 \%$ level (not shown here), supporting the lack of difference in ice nucleation activity between AD and SD. PINC sampled the smallest size fractions of the three chambers since the volume-equivalent cut-off diameter for its impactor was $0.7 \mu \mathrm{m}(1.0 \mu \mathrm{m}$ for CSU-CFDC), whereas AIDA did not sample downstream of an impactor and thus a substantial amount of supermicron particles were sampled. These size cut-offs can result in the lower ice nucleation activities in general observed in PINC, given the ice nucleation activity increases with particle size

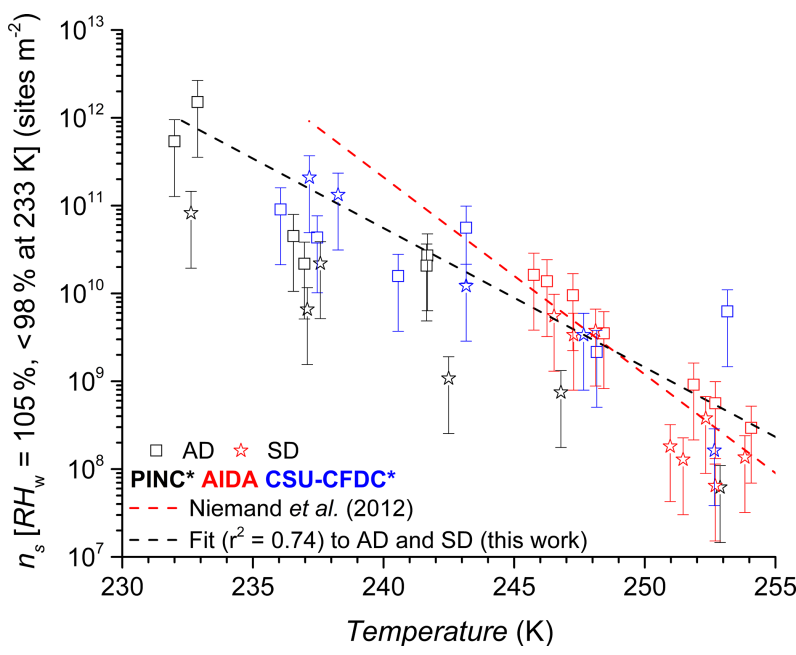

Figure 11. INAS densities as a function of temperature for AD and SD. Error bars are based on $75 \%$ sizing due to spherical assumption and surface area determination and $15 \%$ from particle counting resulting in a relative error of $77 \%$ in $n_{\mathrm{s}}$. The asterisk $\left(^{*}\right)$ denotes that the PINC and CSU-CFDC data have been adjusted by a factor of 3 (see text Sect. 4 for details). Equation for exponential fit (black dashed line) shown in Sect. 4.4.

for a given dust sample type (Archuleta et al., 2005; Welti et al., 2009).

At the warmer end of the temperature range $\sim 253 \mathrm{~K}$, it appears that $\mathrm{SD}$ has lower INAS than $\mathrm{AD}$; however, there is some scatter in the data and also significant overlap between the uncertainties of the data points. One case where AD INAS density is much higher than the rest is for experiment 2 with CSU-CFDC, where a lower impactor cut-off size was used $(0.7 \mu \mathrm{m})$ for this particular experiment before the impactor cut-off was adjusted to the $1.0 \mu \mathrm{m}$ cut-off size stated above. This would matter for INAS density if the particle composition changes with size, which can be the case with mineral dust samples (Vlasenko et al., 2005). However, harder minerals such as feldspars and quartz tend to be enriched in the larger size fractions of the samples and are also the more ice-active particles (compared to softer clay particles), and thus the composition change with size would not explain the high INAS density at this temperature for this experiment. In general from the mineralogy, both $\mathrm{AD}$ and $\mathrm{SD}$ contain clays, feldspars and quartz (Linke et al., 2006; Boose et al., 2016b), with the AD containing significantly more $\mathrm{SiO}_{2}$ (70.4\%, Möhler et al., 2006) than SD (26.8\% Möhler et al., 2006). From the mineralogy, we infer that the AD sample contained more feldspars ( $25 \%$ by mass; Boose et al., 2016b) than the SD sample where Linke et al. (2006) report qualitatively (without mass percentages) that there is a significantly higher fraction of dolomite $\left(\mathrm{CaMg}\left(\mathrm{CO}_{3}\right)_{2}\right)$, calcite $\left(\mathrm{CaCO}_{3}\right)$ and gypsum $\left(\mathrm{CaSO}_{4}\right)$ compared to feldspars. This is consistent with the overall mineralogy reported in Boose et al. (2016b), for Saharan dusts sampled in Morocco, Egypt 
and Tenerife, that there is a smaller feldspar fraction by mass compared to clays, calcites and muscovite in SD compared to AD. Given the general overlap in data across the temperature range sampled and the instruments used, a difference in ice nucleation activity between the AD and SD samples investigated here is not supported. In Fig. 11 we also fit the data with an exponential function to predict the INAS density as function of temperature with the following:

$I N A S_{\text {density }}=e^{a+b T}$,

where INAS density is in active sites per square metre and valid for $255<T<232 \mathrm{~K}$, with fit coefficients of $a=121.4$, $b=-0.403$. This is compared to the parameterization for desert dusts proposed by Niemand et al. (2012, N12) also shown in Fig. 11 for which $a=8.934, b=-0.517$, and $T$ us measured in degrees Celsius. Compared to N12, at warmer temperatures we slightly overestimate INAS density by a factor of 2.5 and at the colder temperatures the fit underestimates INAS density up to a factor of 4.5 compared to N12. The slope of the fit for this work is slightly lower than N12, implying a slightly lower temperature dependency than predicted by N12. However, given the overall scatter in the data for the three chambers used and the uncertainties associated with INAS density, there is good agreement between the fit proposed here and that of N12.

\section{Conclusions}

We present the ice nucleation ability in the immersion mode of two types of natural desert dust samples that were uncoated and coated with the dark ozonolysis products of $\alpha$ pinene as a proxy for atmospheric secondary organic aerosol (SOA). We conclude that the SOA coatings did not affect the immersion ice nucleation ability of the dust particles in the temperature range 253 to $235 \mathrm{~K}$ irrespective of coating thickness $(3-60 \mathrm{~nm})$. This suggests that coatings forming on atmospheric airborne dust during transport via condensation of SOA resulting in ageing will not significantly change the immersion freezing ice nucleation properties of dust particles. Furthermore, the thickness of the coatings in the studies presented here cover a wide range (see Fig. 6) and suggest that in the atmosphere even appreciable amounts (tens of nanometres) of organic coatings (e.g. acids) on dust particles (Sullivan and Prather, 2007) should not impede immersion freezing. We note that we only used two types of mineral dust samples and one proxy of SOA for coating, but given the results from this work and those discussed above from previous work, we cannot assume that condensation of coatings or other chemical processing will impair immersion mode ice nucleation properties of mineral dust particles. Immersion mode ice nucleation is less sensitive (if at all) to coatings and ageing based on this and prior studies on mineral dust. These results are similar to the INP properties in the immersion mode for dust particles exposed to $\mathrm{HNO}_{3}$ or in some cases $\mathrm{H}_{2} \mathrm{SO}_{4}$ vapours that also showed lack of an impairment in immersion freezing ability. As the coated particles are activated into droplets prior to experiencing freezing in the ice nucleation chambers, the coatings may have dissolved to reveal the particle ice-active surface sites. Observations of scatter between the three INP chambers, PINC, CSU-CFDC and AIDA, can be attributed to differences in the evaluation of immersion freezing in continuous flow diffusion chambers where $A F S$ (and by extension INAS density) can for some INPs be a factor of 3-9 lower due to aerosol spread outside of the focussed sample lamina (DeMott et al., 2015; Garimella et al., 2017) than for expansion chambers like AIDA. Considering the timescale of seconds in the CFDC type instruments compared to minutes in AIDA, and the particle size range sampled due to the use of impactors, the results obtained between the INP chambers can be considered to be within good agreement (overlapping error bars) for the $T$ and RH conditions evaluated here. To circumvent confounding effects of particle size and coating thickness, future studies with size-selected particles and carefully controlled coating thickness would be desirable to exclude uncertainties in how particle size and composition influence the ice nucleation activity. Furthermore, INAS spectra of AD and SD obtained here were used to obtain a fit for the ice nucleation activities of the desert dusts. Differences in the ice nucleation activity of $\mathrm{AD}$ and SD were not considered significant here in light of the similar INAS density (within uncertainties and instrument scatter), similar to conclusions reached by DeMott et al. (2015) for the same dust samples. Comparing the bulk (average) mineralogy to assess the particle mineralogy sampled by the cloud chambers which were mostly in the sub-micron to low super-micron size range imposes a limitation in assessing the effects of mineralogy on the ice nucleation activity given that single particles can have different specific compositions. Lastly, the assumption of a constant composition with size that is implicit in the use of INAS density to evaluate the results presented here may bias some of the compared results, but aids in the interpretation of polydisperse samples where accounting for surface area is important.

Data availability. The data presented in this publication are available at the following DOI: https://doi.org/10.3929/ethz-b000334972 (Kanji et al., 2019).

Author contributions. ZAK wrote the paper, synthesized the figures, conducted and analysed PINC measurements. RCS, PJD and AJP conducted measurements on the CSU-CFDC. MN and OM conducted measurements on the AIDA chamber. HS prepared the coating experiments and provided coating thicknesses of dust particles. MN and OM provided size distribution data and hosted the entire measurement campaign at the AIDA facility. ZAK interpreted the ice nucleation data with contributions from CC, MN, PJD, OM and RCS. 
Competing interests. The authors declare that they have no conflict of interest.

Special issue statement. This article is part of the special issue "BACCHUS - Impact of Biogenic versus Anthropogenic emissions on Clouds and Climate: towards a Holistic UnderStanding (ACP/AMT/GMD inter-journal SI)". It is not associated with a conference.

Acknowledgements. The authors would like to acknowledge Lothar Shütz from University of Mainz for the AD2 sample. Zamin A. Kanji acknowledges the funding from the SNF grant number 200021_127275 and Ulrike Lohmann. Cédric Chou acknowledges funding from GAW-CH 2010-2013. Paul J. DeMott, Anthony J. Prenni and Ryan C. Sullivan acknowledge support from US National Science Foundation grants ATM-0611936 and ATM0841602, and travel support from the EUROCHAMP-2 Transnational Access proposal E2-2009-09-15-0009 (PI: Jonathan Crosier) funded within the EC Seventh Framework Program. Ottmar Möhler, Monika Niemand and Harald Saathoff acknowledge funding from the Helmholtz Association through the Virtual Institute on AerosolCloud Interactions (VI-ACI, VH-VI-233). Support by the AIDA technical team for preparing and conducting the cloud chamber experiments is gratefully acknowledged.

Review statement. This paper was edited by Allan Bertram and reviewed by two anonymous referees.

\section{References}

Archuleta, C. M., DeMott, P. J., and Kreidenweis, S. M.: Ice nucleation by surrogates for atmospheric mineral dust and mineral dust/sulfate particles at cirrus temperatures, Atmos. Chem. Phys., 5, 2617-2634, https://doi.org/10.5194/acp-5-2617-2005, 2005.

Arimoto, R., Kim, Y. J., Kim, Y. P., Quinn, P. K., Bates, T. S., Anderson, T. L., Gong, S., Uno, I., Chin, M., Huebert, B. J., Clarke, A. D., Shinozuka, Y., Weber, R. J., Anderson, J. R., Guazzotti, S. A., Sullivan, R. C., Sodeman, D. A., Prather, K. A., and Sokolik, I. N.: Characterization of Asian Dust during ACE-Asia, Global Planet. Change, 52, 23-56, https://doi.org/10.1016/j.gloplacha.2006.02.013, 2006.

Augustin-Bauditz, S., Wex, H., Kanter, S., Ebert, M., Niedermeier, D., Stolz, F., Prager, A., and Stratmann, F.: The immersion mode ice nucleation behavior of mineral dusts: A comparison of different pure and surface modified dusts, Geophys. Res. Lett, 41, 7375-7382, https://doi.org/10.1002/2014GL061317, 2014.

Augustin-Bauditz, S., Wex, H., Denjean, C., Hartmann, S., Schneider, J., Schmidt, S., Ebert, M., and Stratmann, F.: Laboratorygenerated mixtures of mineral dust particles with biological substances: characterization of the particle mixing state and immersion freezing behavior, Atmos. Chem. Phys., 16, 5531-5543, https://doi.org/10.5194/acp-16-5531-2016, 2016.

Bates, T. S., Quinn, P. K., Coffman, D. J., Covert, D. S., Miller, T. L., Johnson, J. E., Carmichael, G. R., Uno, I., Guazzotti, S. A., Sodeman, D. A., Prather, K. A., Rivera, M., Russell, L.
M., and Merrill, J. T.: Marine boundary layer dust and pollutant transport associated with the passage of a frontal system over eastern Asia, J. Geophys. Res.-Atmos., 109, D19S19, https://doi.org/10.1029/2003jd004094, 2004.

Baustian, K. J., Cziczo, D. J., Wise, M. E., Pratt, K. A., Kulkarni, G., Hallar, A. G., and Tolbert, M. A.: Importance of aerosol composition, mixing state, and morphology for heterogeneous ice nucleation: A combined field and laboratory approach, J. Geophys. Res.-Atmos., 117, D06217, https://doi.org/10.1029/2011jd016784, 2012.

Benz, S., Megahed, K., Mohler, O., Saathoff, H., Wagner, R., and Schurath, U.: T-dependent rate measurements of homogeneous ice nucleation in cloud droplets using a large atmospheric simulation chamber, J. Photochem. Photobiol. A-Chem., 176, 208217, https://doi.org/10.1016/j.jphotochem.2005.08.026, 2005.

Beydoun, H., Polen, M., and Sullivan, R. C.: Effect of particle surface area on ice active site densities retrieved from droplet freezing spectra, Atmos. Chem. Phys., 16, 13359-13378, https://doi.org/10.5194/acp-16-13359-2016, 2016.

Boose, Y., Sierau, B., García, M. I., Rodríguez, S., Alastuey, A., Linke, C., Schnaiter, M., Kupiszewski, P., Kanji, Z. A., and Lohmann, U.: Ice nucleating particles in the Saharan Air Layer, Atmos. Chem. Phys., 16, 9067-9087, https://doi.org/10.5194/acp-16-9067-2016, 2016a.

Boose, Y., Welti, A., Atkinson, J., Ramelli, F., Danielczok, A., Bingemer, H. G., Plötze, M., Sierau, B., Kanji, Z. A., and Lohmann, U.: Heterogeneous ice nucleation on dust particles sourced from nine deserts worldwide - Part 1: Immersion freezing, Atmos. Chem. Phys., 16, 15075-15095, https://doi.org/10.5194/acp-16-15075-2016, 2016b.

Burkert-Kohn, M., Wex, H., Welti, A., Hartmann, S., Grawe, S., Hellner, L., Herenz, P., Atkinson, J. D., Stratmann, F., and Kanji, Z. A.: Leipzig Ice Nucleation chamber Comparison (LINC): intercomparison of four online ice nucleation counters, Atmos. Chem. Phys., 17, 11683-11705, https://doi.org/10.5194/acp-1711683-2017, 2017.

Chernoff, D. I. and Bertram, A. K.: Effects of sulfate coatings on the ice nucleation properties of a biological ice nucleus and several types of minerals, J. Geophys. Res.-Atmos., 115, D20205, https://doi.org/10.1029/2010jd014254, 2010.

Chou, C., Stetzer, O., Weingartner, E., Jurányi, Z., Kanji, Z. A., and Lohmann, U.: Ice nuclei properties within a Saharan dust event at the Jungfraujoch in the Swiss Alps, Atmos. Chem. Phys., 11, 4725-4738, https://doi.org/10.5194/acp-11-4725-2011, 2011.

Connolly, P. J., Möhler, O., Field, P. R., Saathoff, H., Burgess, R., Choularton, T., and Gallagher, M.: Studies of heterogeneous freezing by three different desert dust samples, Atmos. Chem. Phys., 9, 2805-2824, https://doi.org/10.5194/acp-9-2805-2009, 2009.

Cziczo, D. J., Froyd, K. D., Hoose, C., Jensen, E. J., Diao, M. H., Zondlo, M. A., Smith, J. B., Twohy, C. H., and Murphy, D. M.: Clarifying the Dominant Sources and Mechanisms of Cirrus Cloud Formation, Science, 340, 1320-1324, https://doi.org/10.1126/science.1234145, 2013.

DeMott, P. J., Cziczo, D. J., Prenni, A. J., Murphy, D. M., Kreidenweis, S. M., Thomson, D. S., Borys, R., and Rogers, D. C.: Measurements of the concentration and composition of nuclei for cirrus formation, P. Natl. Acad. Sci. USA, 100, 14655-14660, 2003a. 
DeMott, P. J., Sassen, K., Poellot, M. R., Baumgardner, D., Rogers, D. C., Brooks, S. D., Prenni, A. J., and Kreidenweis, S. M.: African dust aerosols as atmospheric ice nuclei, Geophys. Res. Lett., 30, 1732, https://doi.org/10.1029/2003GL017410, 2003 b.

DeMott, P. J., Prenni, A. J., Liu, X., Kreidenweis, S. M., Petters, M. D., Twohy, C. H., Richardson, M. S., Eidhammer, T., and Rogers, D. C.: Predicting global atmospheric ice nuclei distributions and their impacts on climate, P. Natl. Acad. Sci. USA, 107, 1121711222, https://doi.org/10.1073/pnas.0910818107, 2010.

DeMott, P. J., Prenni, A. J., McMeeking, G. R., Sullivan, R. C., Petters, M. D., Tobo, Y., Niemand, M., Möhler, O., Snider, J. R., Wang, Z., and Kreidenweis, S. M.: Integrating laboratory and field data to quantify the immersion freezing ice nucleation activity of mineral dust particles, Atmos. Chem. Phys., 15, 393-409, https://doi.org/10.5194/acp-15-393-2015, 2015.

DeMott, P. J., Hill, T. C. J., McCluskey, C. S., Prather, K. A., Collins, D. B., Sullivan, R. C., Ruppel, M. J., Mason, R. H., Irish, V. E., Lee, T., Hwang, C. Y., Rhee, T. S., Snider, J. R., McMeeking, G. R., Dhaniyala, S., Lewis, E. R., Wentzell, J. J. B., Abbatt, J., Lee, C., Sultana, C. M., Ault, A. P., Axson, J. L., Martinez, M. D., Venero, I., Santos-Figueroa, G., Stokes, M. D., Deane, G. B., Mayol-Bracero, O. L., Grassian, V. H., Bertram, T. H., Bertram, A. K., Moffett, B. F., and Franc, G. D.: Sea spray aerosol as a unique source of ice nucleating particles, P. Natl. Acad. Sci. USA, 113, 5797-5803, https://doi.org/10.1073/pnas.1514034112, 2016.

DeMott, P. J., Hill, T. C. J., Petters, M. D., Bertram, A. K., Tobo, Y., Mason, R. H., Suski, K. J., McCluskey, C. S., Levin, E. J. T., Schill, G. P., Boose, Y., Rauker, A. M., Miller, A. J., Zaragoza, J., Rocci, K., Rothfuss, N. E., Taylor, H. P., Hader, J. D., Chou, C., Huffman, J. A., Pöschl, U., Prenni, A. J., and Kreidenweis, S. M.: Comparative measurements of ambient atmospheric concentrations of ice nucleating particles using multiple immersion freezing methods and a continuous flow diffusion chamber, Atmos. Chem. Phys., 17, 11227-11245, https://doi.org/10.5194/acp-1711227-2017, 2017

Eidhammer, T., DeMott, P. J., Prenni, A. J., Petters, M. D., Twohy, C. H., Rogers, D. C., Stith, J., Heymsfield, A., Wang, Z., Pratt, K. A., Prather, K. A., Murphy, S. M., Seinfeld, J. H., Subramanian, R., and Kreidenweis, S. M.: Ice Initiation by Aerosol Particles: Measured and Predicted Ice Nuclei Concentrations versus Measured Ice Crystal Concentrations in an Orographic Wave Cloud, J. Atmos. Sci., 67, 2417-2436, https://doi.org/10.1175/2010jas3266.1, 2010.

Fahey, D. W., Gao, R.-S., Möhler, O., Saathoff, H., Schiller, C., Ebert, V., Krämer, M., Peter, T., Amarouche, N., Avallone, L. M., Bauer, R., Bozóki, Z., Christensen, L. E., Davis, S. M., Durry, G., Dyroff, C., Herman, R. L., Hunsmann, S., Khaykin, S. M., Mackrodt, P., Meyer, J., Smith, J. B., Spelten, N., Troy, R. F., Vömel, H., Wagner, S., and Wienhold, F. G.: The AquaVIT-1 intercomparison of atmospheric water vapor measurement techniques, Atmos. Meas. Tech., 7, 3177-3213, https://doi.org/10.5194/amt-73177-2014, 2014.

Freedman, M. A.: Potential Sites for Ice Nucleation on Aluminosilicate Clay Minerals and Related Materials, J. Phys. Chem. Lett., 6, 3850-3858, https://doi.org/10.1021/acs.jpclett.5b01326, 2015 .
Fukuta, N.: Experimental Studies of Organic Ice Nuclei, J. Atmos. Sci., 23, 191-196, https://doi.org/10.1175/15200469(1966)023<0191:ESOOIN>2.0.CO;2, 1966.

Garimella, S., Rothenberg, D. A., Wolf, M. J., David, R. O., Kanji, Z. A., Wang, C., Rösch, M., and Cziczo, D. J.: Uncertainty in counting ice nucleating particles with continuous flow diffusion chambers, Atmos. Chem. Phys., 17, 10855-10864, https://doi.org/10.5194/acp-17-10855-2017, 2017.

Gorkowski, K., Donahue, N. M., and Sullivan, R. C.: Emulsified and Liquid-Liquid Phase-Separated States of $\alpha$-Pinene Secondary Organic Aerosol Determined Using Aerosol Optical Tweezers, Environ. Sci. Technol., 51, 12154-12163, https://doi.org/10.1021/acs.est.7b03250, 2017.

Hallquist, M., Wenger, J. C., Baltensperger, U., Rudich, Y., Simpson, D., Claeys, M., Dommen, J., Donahue, N. M., George, C., Goldstein, A. H., Hamilton, J. F., Herrmann, H., Hoffmann, T., Iinuma, Y., Jang, M., Jenkin, M. E., Jimenez, J. L., Kiendler-Scharr, A., Maenhaut, W., McFiggans, G., Mentel, Th. F., Monod, A., Prévôt, A. S. H., Seinfeld, J. H., Surratt, J. D., Szmigielski, R., and Wildt, J.: The formation, properties and impact of secondary organic aerosol: current and emerging issues, Atmos. Chem. Phys., 9, 5155-5236, https://doi.org/10.5194/acp9-5155-2009, 2009.

Hill, T. C. J., Moffett, B. F., DeMott, P. J., Georgakopoulos, D. G., Stump, W. L., and Franc, G. D.: Measurement of Ice Nucleation-Active Bacteria on Plants and in Precipitation by Quantitative PCR, Appl. Environ. Microb., 80, 1256-1267, https://doi.org/10.1128/aem.02967-13, 2014.

Hiranuma, N., Augustin-Bauditz, S., Bingemer, H., Budke, C., Curtius, J., Danielczok, A., Diehl, K., Dreischmeier, K., Ebert, M., Frank, F., Hoffmann, N., Kandler, K., Kiselev, A., Koop, T., Leisner, T., Möhler, O., Nillius, B., Peckhaus, A., Rose, D., Weinbruch, S., Wex, H., Boose, Y., DeMott, P. J., Hader, J. D., Hill, T. C. J., Kanji, Z. A., Kulkarni, G., Levin, E. J. T., McCluskey, C. S., Murakami, M., Murray, B. J., Niedermeier, D., Petters, M. D., O’Sullivan, D., Saito, A., Schill, G. P., Tajiri, T., Tolbert, M. A., Welti, A., Whale, T. F., Wright, T. P., and Yamashita, K.: A comprehensive laboratory study on the immersion freezing behavior of illite NX particles: a comparison of 17 ice nucleation measurement techniques, Atmos. Chem. Phys., 15, 2489-2518, https://doi.org/10.5194/acp-15-2489-2015, 2015.

Hoose, C. and Möhler, O.: Heterogeneous ice nucleation on atmospheric aerosols: a review of results from laboratory experiments, Atmos. Chem. Phys., 12, 9817-9854, https://doi.org/10.5194/acp-12-9817-2012, 2012.

Huffman, J. A., Prenni, A. J., DeMott, P. J., Pöhlker, C., Mason, R. H., Robinson, N. H., Fröhlich-Nowoisky, J., Tobo, Y., Després, V. R., Garcia, E., Gochis, D. J., Harris, E., MüllerGermann, I., Ruzene, C., Schmer, B., Sinha, B., Day, D. A., Andreae, M. O., Jimenez, J. L., Gallagher, M., Kreidenweis, S. M., Bertram, A. K., and Pöschl, U.: High concentrations of biological aerosol particles and ice nuclei during and after rain, Atmos. Chem. Phys., 13, 6151-6164, https://doi.org/10.5194/acp13-6151-2013, 2013.

Ignatius, K., Kristensen, T. B., Järvinen, E., Nichman, L., Fuchs, C., Gordon, H., Herenz, P., Hoyle, C. R., Duplissy, J., Garimella, S., Dias, A., Frege, C., Höppel, N., Tröstl, J., Wagner, R., Yan, C., Amorim, A., Baltensperger, U., Curtius, J., Donahue, N. M., Gallagher, M. W., Kirkby, J., Kulmala, M., Möhler, O., Saathoff, H., 
Schnaiter, M., Tomé, A., Virtanen, A., Worsnop, D., and Stratmann, F.: Heterogeneous ice nucleation of viscous secondary organic aerosol produced from ozonolysis of a-pinene, Atmos. Chem. Phys., 16, 6495-6509, https://doi.org/10.5194/acp-166495-2016, 2016.

Jurányi, Z., Gysel, M., Duplissy, J., Weingartner, E., Tritscher, T., Dommen, J., Henning, S., Ziese, M., Kiselev, A., Stratmann, F., George, I., and Baltensperger, U.: Influence of gas-to-particle partitioning on the hygroscopic and droplet activation behaviour of $\alpha$-pinene secondary organic aerosol, Phys. Chem. Chem. Phys., 11, 8091-8097, https://doi.org/10.1039/B904162A, 2009.

Kanji, Z. A. and Abbatt, J. P. D.: The University of Toronto Continuous Flow Diffusion Chamber (UT-CFDC): A Simple Design for Ice Nucleation Studies, Aerosol Sci. Tech., 43, 730-738, 2009.

Kanji, Z. A. and Abbatt, J. P. D.: Ice Nucleation onto Arizona Test Dust at Cirrus Temperatures: Effect of Temperature and Aerosol Size on Onset Relative Humidity, J. Phys. Chem. A., 114, 935941, https://doi.org/10.1021/jp908661m, 2010.

Kanji, Z. A., Welti, A., Chou, C., Stetzer, O., and Lohmann, U.: Laboratory studies of immersion and deposition mode ice nucleation of ozone aged mineral dust particles, Atmos. Chem. Phys., 13, 9097-9118, https://doi.org/10.5194/acp-139097-2013, 2013.

Kanji, Z. A., Ladino, L. A., Wex, H., Boose, Y., BurkertKohn, M., Cziczo, D. J., and Krämer, M.: Overview of Ice Nucleating Particles, Meteor. Monogr., 58, 1.1-1.33, https://doi.org/10.1175/AMSMONOGRAPHS-D-16-0006.1, 2017

Kanji, Z. A., Sullivan, R. C., Niemand, M., DeMott, P. J., Prenni, A. J., Chou, C., Saathoff, H., and Möhler, O.: Heterogeneous Ice Nucleation Properties of Natural Desert Dust Particles Coated with a Surrogate of Secondary Organic Aerosol, Dataset, https://doi.org/10.3929/ethz-b-000334972, 2019.

Kidd, C., Perraud, V., Wingen, L. M., and Finlayson-Pitts, B. J.: Integrating phase and composition of secondary organic aerosol from the ozonolysis of alpha-pinene, P. Natl. Acad. Sci. USA, 111, 7552-7557, https://doi.org/10.1073/pnas.1322558111, 2014.

Knopf, D. A. and Forrester, S. M.: Freezing of Water and Aqueous $\mathrm{NaCl}$ Droplets Coated by Organic Monolayers as a Function of Surfactant Properties and Water Activity, J. Phys. Chem. A, 115, 5579-5591, https://doi.org/10.1021/jp2014644, 2011.

Knopf, D. A., Wang, B., Laskin, A., Moffet, R. C., and Gilles, M. K.: Heterogeneous nucleation of ice on anthropogenic organic particles collected in Mexico City, Geophys. Res. Lett., 37, L11803, https://doi.org/10.1029/2010g1043362, 2010.

Knopf, D. A., Alpert, P. A., Wang, B., O'Brien, R. E., Kelly, S. T., Laskin, A., Gilles, M. K., and Moffet, R. C.: Microspectroscopic imaging and characterization of individually identified ice nucleating particles from a case field study, J. Geophys. Res.-Atmos., 119, 2014JD021866, https://doi.org/10.1002/2014JD021866, 2014.

Knopf, D. A., Alpert, P. A., and Wang, B.: The Role of Organic Aerosol in Atmospheric Ice Nucleation: A Review, ACS Earth and Space Chem., 2, 168-202, https://doi.org/10.1021/acsearthspacechem.7b00120, 2018.

Koop, T., Bookhold, J., Shiraiwa, M., and Pöschl, U.: Glass transition and phase state of organic compounds: dependency on molecular properties and implications for secondary organic aerosols in the atmosphere, Phys. Chem. Chem. Phys., 13, 19238-19255, https://doi.org/10.1039/c1cp22617g, 2011.

Korolev, A.: Limitations of the wegener-bergeron-findeisen mechanism in the evolution of mixed-phase clouds, J. Atmos. Sci., 64, 3372-3375, https://doi.org/10.1175/jas4035.1, 2007.

Kulkarni, G., Sanders, C., Zhang, K., Liu, X., and Zhao, C.: Ice nucleation of bare and sulfuric acid-coated mineral dust particles and implication for cloud properties, J. Geophys. Res.-Atmos., 119, 2014JD021567, https://doi.org/10.1002/2014JD021567, 2014.

Kulkarni, G., Zhang, K., Zhao, C., Nandasiri, M., Shutthanandan, V., Liu, X., Fast, J., and Berg, L.: Ice formation on nitric acid-coated dust particles: Laboratory and modeling studies, J. Geophys. Res.-Atmos., 120, 7682-7698, https://doi.org/10.1002/2014JD022637, 2015.

Kumar, A., Marcolli, C., Luo, B., and Peter, T.: Ice nucleation activity of silicates and aluminosilicates in pure water and aqueous solutions - Part 1: The K-feldspar microcline, Atmos. Chem. Phys., 18, 7057-7079, https://doi.org/10.5194/acp18-7057-2018, 2018.

Ladino, L. A., Zhou, S., Yakobi-Hancock, J. D., Aljawhary, D., and Abbatt, J. P. D.: Factors controlling the ice nucleating abilities of $\alpha$-pinene SOA particles, J. Geophys. Res.-Atmos., 119, 90419051, https://doi.org/10.1002/2014JD021578, 2014.

Ladino, L. A., Yakobi-Hancock, J. D., Kilthau, W. P., Mason, R. H., Si, M., Li, J., Miller, L. A., Schiller, C. L., Huffman, J. A., Aller, J. Y., Knopf, D. A., Bertram, A. K., and Abbatt, J. P. D.: Addressing the ice nucleating abilities of marine aerosol: A combination of deposition mode laboratory and field measurements, Atmos. Environ., 132, 1-10, https://doi.org/10.1016/j.atmosenv.2016.02.028, 2016.

Li, W., Shao, L., Shi, Z., Chen, J., Yang, L., Yuan, Q., Yan, C., Zhang, X., Wang, Y., Sun, J., Zhang, Y., Shen, X., Wang, Z., and Wang, W.: Mixing state and hygroscopicity of dust and haze particles before leaving Asian continent, J. Geophys. Res.-Atmos. , 119, 2013JD021003, https://doi.org/10.1002/2013JD021003, 2014.

Linke, C., Möhler, O., Veres, A., Mohácsi, Á., Bozóki, Z., Szabó, G., and Schnaiter, M.: Optical properties and mineralogical composition of different Saharan mineral dust samples: a laboratory study, Atmos. Chem. Phys., 6, 3315-3323, https://doi.org/10.5194/acp-6-3315-2006, 2006.

Liu, P., Li, Y. J., Wang, Y., Gilles, M. K., Zaveri, R. A., Bertram, A. K., and Martin, S. T.: Lability of secondary organic particulate matter, P. Natl. Acad. Sci. USA, 113, 12643-12648, https://doi.org/10.1073/pnas.1603138113, 2016.

Lüönd, F., Stetzer, O., Welti, A., and Lohmann, U.: Experimental study on the ice nucleation ability of size-selected kaolinite particles in the immersion mode, J. Geophys. Res.-Atmos., 115, D14201, https://doi.org/10.1029/2009jd012959, 2010.

Maclean, A. M., Butenhoff, C. L., Grayson, J. W., Barsanti, K., Jimenez, J. L., and Bertram, A. K.: Mixing times of organic molecules within secondary organic aerosol particles: a global planetary boundary layer perspective, Atmos. Chem. Phys., 17, 13037-13048, https://doi.org/10.5194/acp-17-130372017, 2017.

Maria, S. F., Russell, L. M., Gilles, M. K., and Myneni, S. C. B.: Organic aerosol growth mechanisms and 
their climate-forcing implications, Science, 306, 1921-1924, https://doi.org/10.1126/science.1103491, 2004.

McCluskey, C. S., Hill, T. C. J., Malfatti, F., Sultana, C. M., Lee, C., Santander, M. V., Beall, C. M., Moore, K. A., Cornwell, G. C., Collins, D. B., Prather, K. A., Jayarathne, T., Stone, E. A., Azam, F., Kreidenweis, S. M., and DeMott, P. J.: A Dynamic Link between Ice Nucleating Particles Released in Nascent Sea Spray Aerosol and Oceanic Biological Activity during Two Mesocosm Experiments, J. Atmos. Sci., 74, 151-166, https://doi.org/10.1175/JAS-D-16-0087.1, 2016.

McFiggans, G.: Readily Mixed Atmospheric Organic Particles, Chem, 4, 399-401, https://doi.org/10.1016/j.chempr.2018.02.017, 2018.

Megahed, K.: The Impact of Mineral Dust Aerosol Particles on Cloud Formation, PhD Thesis, Mathematics and Natural Sciences Universität Bonn, Bonn, Germany, 2007.

Möhler, O., Field, P. R., Connolly, P., Benz, S., Saathoff, H., Schnaiter, M., Wagner, R., Cotton, R., Krämer, M., Mangold, A., and Heymsfield, A. J.: Efficiency of the deposition mode ice nucleation on mineral dust particles, Atmos. Chem. Phys., 6, 30073021, https://doi.org/10.5194/acp-6-3007-2006, 2006.

Möhler, O., Benz, S., Saathoff, H., Schnaiter, M., Wagner, R., Schneider, J., Walter, S., Ebert, V., and Wagner, S.: The effect of organic coating on the heterogeneous ice nucleation efficiency of mineral dust aerosols, Environ. Res. Lett., 3, 025007, https://doi.org/10.1088/1748-9326/3/2/025007, 2008.

Murray, B. J., Wilson, T. W., Dobbie, S., Cui, Z. Q., Al-Jumur, S., Mohler, O., Schnaiter, M., Wagner, R., Benz, S., Niemand, M., Saathoff, H., Ebert, V., Wagner, S., and Karcher, B.: Heterogeneous nucleation of ice particles on glassy aerosols under cirrus conditions, Nat. Geosci., 3, 233-237, 2010.

Murray, B. J., O’Sullivan, D., Atkinson, J. D., and Webb, M. E.: Ice nucleation by particles immersed in supercooled cloud droplets, Chem. Soc. Rev., 41, 6519-6554, https://doi.org/10.1039/c2cs35200a, 2012.

Niedermeier, D., Hartmann, S., Clauss, T., Wex, H., Kiselev, A., Sullivan, R. C., DeMott, P. J., Petters, M. D., Reitz, P., Schneider, J., Mikhailov, E., Sierau, B., Stetzer, O., Reimann, B., Bundke, U., Shaw, R. A., Buchholz, A., Mentel, T. F., and Stratmann, F.: Experimental study of the role of physicochemical surface processing on the IN ability of mineral dust particles, Atmos. Chem. Phys., 11, 11131-11144, https://doi.org/10.5194/acp-11-111312011, 2011a.

Niedermeier, D., Hartmann, S., Clauss, T., Wex, H., Kiselev, A., Sullivan, R. C., DeMott, P. J., Petters, M. D., Reitz, P., Schneider, J., Mikhailov, E., Sierau, B., Stetzer, O., Reimann, B., Bundke, U., Shaw, R. A., Buchholz, A., Mentel, T. F., and Stratmann, F.: Corrigendum to "Experimental study of the role of physicochemical surface processing on the IN ability of mineral dust particles" published in Atmos. Chem. Phys., 11, 11131-11144, 2011, Atmos. Chem. Phys., 11, 11919-11919, https://doi.org/10.5194/acp-11-11919-2011, 2011 b.

Niemand, M.: A Particle-Surface-Area-Based Formulation of Heterogeneous Ice Nucleation by Mineral Dust Aerosols, $\mathrm{PhD}$ Thesis, available at: https://publikationen.bibliothek.kit. edu/1000030381 (last access: 11 April 2019), 2012.

Niemand, M., Mohler, O., Vogel, B., Vogel, H., Hoose, C., Connolly, P., Klein, H., Bingemer, H., DeMott, P., Skrotzki, J., and Leisner, T.: A Particle-Surface-Area-Based Parameterization of
Immersion Freezing on Desert Dust Particles, J. Atmos. Sci., 69 , 3077-3092, https://doi.org/10.1175/jas-d-11-0249.1, 2012.

Panda, A. K., Mishra, B. G., Mishra, D. K., and Singh, R. K.: Effect of sulphuric acid treatment on the physico-chemical characteristics of kaolin clay, Colloid Surface. A, 363, 98-104, https://doi.org/10.1016/j.colsurfa.2010.04.022, 2010.

Parsons, M. T., Knopf, D. A., and Bertram, A. K.: Deliquescence and crystallization of ammonium sulfate particles internally mixed with water-soluble organic compounds, J. Phys. Chem. A, 108, 11600-11608, 2004.

Petters, M. D., Parsons, M. T., Prenni, A. J., DeMott, P. J., Kreidenweis, S. M., Carrico, C. M., Sullivan, A. P., McMeeking, G. R., Levin, E., Wold, C. E., Collett, J. L., and Moosmuller, H.: Ice nuclei emissions from biomass burning, J. Geophys. Res.-Atmos., 114, D07209, https://doi.org/10.1029/2008jd011532, 2009.

Prenni, A. J., Petters, M. D., Faulhaber, A., Carrico, C. M., Ziemann, P. J., Kreidenweis, S. M., and DeMott, P. J.: Heterogeneous ice nucleation measurements of secondary organic aerosol generated from ozonolysis of alkenes, Geophys. Res. Lett., 36, L06808, https://doi.org/10.1029/2008GL036957, 2009.

Prenni, A. J., Tobo, Y., Garcia, E., DeMott, P. J., Huffman, J. A., McCluskey, C. S., Kreidenweis, S. M., Prenni, J. E., Pohlker, C., and Pöschl, U.: The impact of rain on ice nuclei populations at a forested site in Colorado, Geophys. Res. Lett., 40, 227-231, https://doi.org/10.1029/2012g1053953, 2013.

Qiu, Y., Odendahl, N., Hudait, A., Mason, R., Bertram, A. K., Paesani, F., DeMott, P. J., and Molinero, V.: Ice Nucleation Efficiency of Hydroxylated Organic Surfaces Is Controlled by Their Structural Fluctuations and Mismatch to Ice, J. Am. Chem. Soc., 139, 3052-3064, https://doi.org/10.1021/jacs.6b12210, 2017.

Reitz, P., Spindler, C., Mentel, T. F., Poulain, L., Wex, H., Mildenberger, K., Niedermeier, D., Hartmann, S., Clauss, T., Stratmann, F., Sullivan, R. C., DeMott, P. J., Petters, M. D., Sierau, B., and Schneider, J.: Surface modification of mineral dust particles by sulphuric acid processing: implications for ice nucleation abilities, Atmos. Chem. Phys., 11, 7839-7858, https://doi.org/10.5194/acp-11-7839-2011, 2011.

Richardson, M. S., DeMott, P. J., Kreidenweis, S. M., Cziczo, D. J., Dunlea, E. J., Jimenez, J. L., Thomson, D. S., Ashbaugh, L. L., Borys, R. D., Westphal, D. L., Casuccio, G. S., and Lersch, T. L.: Measurements of heterogeneous ice nuclei in the western United States in springtime and their relation to aerosol characteristics, J. Geophys. Res.-Atmos., 112, D02209, https://doi.org/10.1029/2006jd007500, 2007.

Rogers, D. C.: Development of a continuous flow thermal diffusion chamber for ice nucleation studies, Atmos. Res., 22, 149-181, 1988.

Rogers, D. C., DeMott, P. J., Kreidenweis, S. M., and Chen, Y. L.: A continuous-flow diffusion chamber for airborne measurements of ice nuclei, J. Atmos. Ocean. Tech., 18, 725-741, 2001.

Russell, L. M., Maria, S. F., and Myneni, S. C. B.: Mapping organic coatings on atmospheric particles, Geophys. Res. Lett., 29, 261-26-4, https://doi.org/10.1029/2002g1014874, 2002.

Saathoff, H., Naumann, K.-H., Möhler, O., Jonsson, Å. M., Hallquist, M., Kiendler-Scharr, A., Mentel, Th. F., Tillmann, R., and Schurath, U.: Temperature dependence of yields of secondary organic aerosols from the ozonolysis of a-pinene and limonene, Atmos. Chem. Phys., 9, 1551-1577, https://doi.org/10.5194/acp9-1551-2009, 2009. 
Schill, G. P., De Haan, D. O., and Tolbert, M. A.: Heterogeneous ice nucleation on simulated secondary organic aerosol, Environ. Sci. Technol., 48, 1675-1682, https://doi.org/10.1021/es4046428, 2014.

Shi, Z., Zhang, D., Hayashi, M., Ogata, H., Ji, H., and Fujiie, W.: Influences of sulfate and nitrate on the hygroscopic behaviour of coarse dust particles, Atmos. Environ., 42, 822-827, https://doi.org/10.1016/j.atmosenv.2007.10.037, 2008.

Shilling, J. E., Fortin, T. J., and Tolbert, M. A.: Depositional ice nucleation on crystalline organic and inorganic solids, J. Geophys. Res.-Atmos., 111, D12204, https://doi.org/10.1029/2005JD006664, 2006.

Sihvonen, S. K., Schill, G. P., Lyktey, N. A., Veghte, D. P., Tolbert, M. A., and Freedman, M. A.: Chemical and Physical Transformations of Aluminosilicate Clay Minerals Due to Acid Treatment and Consequences for Heterogeneous Ice Nucleation, J. Phys. Chem. A, 118, 8787-8796, https://doi.org/10.1021/jp504846g, 2014.

Steinke, I., Funk, R., Busse, J., Iturri, A., Kirchen, S., Leue, M., Möhler, O., Schwartz, T., Schnaiter, M., Sierau, B., Toprak, E., Ullrich, R., Ulrich, A., Hoose, C., and Leisner, T.: Ice nucleation activity of agricultural soil dust aerosols from Mongolia, Argentina, and Germany, J. Geophys. Res.-Atmos., 121, 1355913576, https://doi.org/10.1002/2016JD025160, 2016.

Sullivan, R. C. and Prather, K. A.: Investigations of the diurnal cycle and mixing state of oxalic acid in individual particles in Asian aerosol outflow, Environ. Sci. Technol., 41, 8062-8069, https://doi.org/10.1021/es071134g, 2007.

Sullivan, R. C., Guazzotti, S. A., Sodeman, D. A., and Prather, K. A.: Direct observations of the atmospheric processing of Asian mineral dust, Atmos. Chem. Phys., 7, 1213-1236, https://doi.org/10.5194/acp-7-1213-2007, 2007a.

Sullivan, R. C., Guazzotti, S. A., Sodeman, D. A., Tang, Y. H., Carmichael, G. R., and Prather, K. A.: Mineral dust is a sink for chlorine in the marine boundary layer, Atmos. Environ., 41, 7166-7179, https://doi.org/10.1016/j.atmosenv.2007.05.047, $2007 b$.

Sullivan, R. C., Minambres, L., DeMott, P. J., Prenni, A. J., Carrico, C. M., Levin, E. J. T., and Kreidenweis, S. M.: Chemical processing does not always impair heterogeneous ice nucleation of mineral dust particles, Geophys. Res. Lett., 37, L24805, https://doi.org/10.1029/2010g1045540, 2010a.

Sullivan, R. C., Petters, M. D., DeMott, P. J., Kreidenweis, S. M., Wex, H., Niedermeier, D., Hartmann, S., Clauss, T., Stratmann, F., Reitz, P., Schneider, J., and Sierau, B.: Irreversible loss of ice nucleation active sites in mineral dust particles caused by sulphuric acid condensation, Atmos. Chem. Phys., 10, 1147111487, https://doi.org/10.5194/acp-10-11471-2010, 2010b.

Tang, M., Cziczo, D. J., and Grassian, V. H.: Interactions of Water with Mineral Dust Aerosol: Water Adsorption, Hygroscopicity, Cloud Condensation, and Ice Nucleation, Chem. Rev., 116, 4205-4259, https://doi.org/10.1021/acs.chemrev.5b00529, 2016.

Tobo, Y., Zhang, D. Z., Nakata, N., Yamada, M., Ogata, H., Hara, K., and Iwasaka, Y.: Hygroscopic mineral dust particles as influenced by chlorine chemistry in the marine atmosphere, Geophys. Res. Lett., 36, L05817, https://doi.org/10.1029/2008gl036883, 2009.

Tobo, Y., DeMott, P. J., Raddatz, M., Niedermeier, D., Hartmann, S., Kreidenweis, S. M., Stratmann, F., and Wex, H.: Impacts of chemical reactivity on ice nucleation of kaolinite particles: A case study of levoglucosan and sulfuric acid, Geophys. Res. Lett., 39, L19803, https://doi.org/10.1029/2012g1053007, 2012.

Tobo, Y., DeMott, P. J., Hill, T. C. J., Prenni, A. J., SwobodaColberg, N. G., Franc, G. D., and Kreidenweis, S. M.: Organic matter matters for ice nuclei of agricultural soil origin, Atmos. Chem. Phys., 14, 8521-8531, https://doi.org/10.5194/acp14-8521-2014, 2014.

Ullrich, R., Hoose, C., Möhler, O., Niemand, M., Wagner, R., Höhler, K., Hiranuma, N., Saathoff, H., and Leisner, T.: A New Ice Nucleation Active Site Parameterization for Desert Dust and Soot, J. Atmos. Sci., 74, 699-717, https://doi.org/10.1175/JASD-16-0074.1, 2017.

Vlasenko, A., Sjogren, S., Weingartner, E., Gaggeler, H. W., and Ammann, M.: Generation of submicron Arizona test dust aerosol: Chemical and hygroscopic properties, Aerosol Sci. Tech., 39, 452-460, https://doi.org/10.1080/027868290959870, 2005.

Wagner, R., Möhler, O., Saathoff, H., Schnaiter, M., and Leisner, T.: New cloud chamber experiments on the heterogeneous ice nucleation ability of oxalic acid in the immersion mode, Atmos. Chem. Phys., 11, 2083-2110, https://doi.org/10.5194/acp11-2083-2011, 2011.

Wagner, R., Möhler, O., Saathoff, H., Schnaiter, M., Skrotzki, J., Leisner, T., Wilson, T. W., Malkin, T. L., and Murray, B. J.: Ice cloud processing of ultra-viscous/glassy aerosol particles leads to enhanced ice nucleation ability, Atmos. Chem. Phys., 12, 85898610, https://doi.org/10.5194/acp-12-8589-2012, 2012.

Wagner, R., Möhler, O., Saathoff, H., and Schnaiter, M.: Enhanced high-temperature ice nucleation ability of crystallized aerosol particles after preactivation at low temperature, J. Geophys. Res.-Atmos., 119, 8212-8230, https://doi.org/10.1002/2014JD021741, 2014.

Wagner, R., Höhler, K., Möhler, O., Saathoff, H., and Schnaiter, M.: Crystallization and immersion freezing ability of oxalic and succinic acid in multi-component aqueous organic aerosol particles, Geophys. Res. Lett., 42, 2464-2472, https://doi.org/10.1002/2015GL063075, 2015.

Wang, B. B., Lambe, A. T., Massoli, P., Onasch, T. B., Davidovits, P., Worsnop, D. R., and Knopf, D. A.: The deposition ice nucleation and immersion freezing potential of amorphous secondary organic aerosol: Pathways for ice and mixedphase cloud formation, J. Geophys. Res.-Atmos., 117, D16209, https://doi.org/10.1029/2012jd018063, 2012a.

Wang, B. B., Laskin, A., Roedel, T., Gilles, M. K., Moffet, R. C., Tivanski, A. V., and Knopf, D. A.: Heterogeneous ice nucleation and water uptake by field-collected atmospheric particles below 273 K, J. Geophys. Res.-Atmos., 117, D00V19, https://doi.org/10.1029/2012jd017446, 2012b.

Welti, A., Lüönd, F., Stetzer, O., and Lohmann, U.: Influence of particle size on the ice nucleating ability of mineral dusts, Atmos. Chem. Phys., 9, 6705-6715, https://doi.org/10.5194/acp-9-67052009, 2009.

Welti, A., Lüönd, F., Kanji, Z. A., Stetzer, O., and Lohmann, U.: Time dependence of immersion freezing: an experimental study on size selected kaolinite particles, Atmos. Chem. Phys., 12, 9893-9907, https://doi.org/10.5194/acp-12-9893-2012, 2012.

Welti, A., Kanji, Z. A., Stetzer, O., Lohmann, U., and Lüönd, F.: Exploring the Mechanisms of Ice Nucleation on Kaolinite: From 
Deposition Nucleation to Condensation Freezing, J. Atmos. Sci., 71, 16-36, https://doi.org/10.1175/jas-d-12-0252.1, 2014.

Wex, H., DeMott, P. J., Tobo, Y., Hartmann, S., Rösch, M., Clauss, T., Tomsche, L., Niedermeier, D., and Stratmann, F.: Kaolinite particles as ice nuclei: learning from the use of different kaolinite samples and different coatings, Atmos. Chem. Phys., 14, 55295546, https://doi.org/10.5194/acp-14-5529-2014, 2014.

Whale, T. F., Holden, M. A., Wilson, T., O'Sullivan, D., and Murray, B. J.: The enhancement and suppression of immersion mode heterogeneous ice-nucleation by solutes, Chem. Sci., 9, 4142-4151, https://doi.org/10.1039/C7SC05421A, 2018.

Wilson, T. W., Murray, B. J., Wagner, R., Möhler, O., Saathoff, H., Schnaiter, M., Skrotzki, J., Price, H. C., Malkin, T. L., Dobbie, S., and Al-Jumur, S. M. R. K.: Glassy aerosols with a range of compositions nucleate ice heterogeneously at cirrus temperatures, Atmos. Chem. Phys., 12, 8611-8632, https://doi.org/10.5194/acp12-8611-2012, 2012.
Wilson, T. W., Ladino, L. A., Alpert, P. A., Breckels, M. N., Brooks, I. M., Browse, J., Burrows, S. M., Carslaw, K. S., Huffman, J. A., Judd, C., Kilthau, W. P., Mason, R. H., McFiggans, G., Miller, L. A., Najera, J. J., Polishchuk, E., Rae, S., Schiller, C. L., Si, M., Temprado, J. V., Whale, T. F., Wong, J. P. S., Wurl, O., Yakobi-Hancock, J. D., Abbatt, J. P. D., Aller, J. Y., Bertram, A. K., Knopf, D. A., and Murray, B. J.: A marine biogenic source of atmospheric ice-nucleating particles, Nature, 525, 234-238, https://doi.org/10.1038/nature14986, 2015.

Wise, M. E., Baustian, K. J., and Tolbert, M. A.: Internally mixed sulfate and organic particles as potential ice nuclei in the tropical tropopause region, P. Natl. Acad. Sci. USA, 107, 6693-6698, https://doi.org/10.1073/pnas.0913018107, 2010.

Ye, Q., Robinson, E. S., Ding, X., Ye, P., Sullivan, R. C., and Donahue, N. M.: Mixing of secondary organic aerosols versus relative humidity, P. Natl. Acad. Sci. USA, 113, 12649-12654, https://doi.org/10.1073/pnas.1604536113, 2016. 